Persp. Teol. 32 (2000) 187-220

\title{
A PARTICIPAÇÃo dA ASSEMBlÉIA dOS FiÉIS NA CELEBRAÇÃo EUCARÍSTICA AO LONGO DA HISTÓRIA: E-VOLUÇÃO OU IN-VOLUÇÃO?
}

José Raimundo de Melo SJ

A função e o significado da assembléia cristã reunida para a celebração nos é atestado tanto na tradição do Novo Testamento, como em documentos que descrevem a ação e a vida da Igreja na era patrística. Nessas assembléias iniciais, o povo não se comportava como frio ouvinte ou mudo espectador. Ao contrário, a sua participação viva, consciente e atuante constituía um elemento sem o qual a celebração não tinha sentido. O povo era sempre convocado por Deus para participar plenamente, em especial, da ceia eucarística. E, na participação-resposta do povo, estava a razão de ser da assembléia reunida. Quando assistimos hoje a tantas tentativas de redescoberta, a nível teológico e litúrgico, do sentido profundo da assembléia do povo cristão no seio da Igreja, uma retomada de suas raízes históricas se faz útil e necessária, seja para iluminar o presente, seja para conduzir com segurança e abertura ao futuro.

O presente estudo, pela extensão temporal que almeja abraçar, analisa a participação na eucaristia ao longo da história cristã de forma assaz resumida. Na verdade, é muito difícil lançar um golpe de vista tão amplo sem cair em reduções interpretativas e erros históricos. Nosso escopo, porém, é apenas ir observando as manifestações e tendências mais significativas em cada época, para tomarmos consci- 
ência de como propriamente se concretiza a participação na assembléia nos diversos períodos da história.

O artigo se divide em duas partes: 1) Das origens ao Concílio de Trento; 2) De Trento ao Vaticano II. De certa forma, este trabalho complementa-se por um outro, a ser publicado num futuro próximo: "A participação ativa na liturgia: grande aspiração da reforma litúrgica do Vaticano II", no qual analisamos a questão da participação dos fiéis nos tempos que vão desde a realização do Concílio Vaticano II até os momentos atuais.

\section{PRIMEIRA PARTE}

\section{A participação do povo na eucaristia: Das origens cristãs ao Concílio de Trento}

\section{A assembléia cristã até o IV século}

A participação do povo cristão nas assembléias de culto nas origens da Igreja, consoante nos relatam importantes fontes da época, era intensa e variada. Não podia ser diferente o comportamento dos primeiros cristãos quando juntos se reuniam em comum: com a experiência do Ressuscitado bem nítida e aquecida em seus corações, participar significava para eles, em definitivo, viver.

Os primeiros cristãos tinham clara consciência do culto que vinha sendo realizado por Israel no Antigo Testamento, composto, em sua maioria, de sacrifícios oferecidos no Templo, vazios de espírito e rico de exterioridade, tantas vezes e de tantos modos duramente criticados pelos profetas, por não serem verdadeira expressão de amor e agradecimento a Deus pelos benefícios recebidos ou sinal de conversão dos pecados. Israel, embora convocado a desenvolver um culto prevalentemente espiritual, de intimidade com Javé, excluindo-se talvez algum momento do período do deserto (Jr 2,2-3; Os 2,17) ${ }^{1}$, ou daquele que segue logo após o exílio, este ideal infelizmente não se concretizara. Sacrifícios não faltavam, mas não revelavam o íntimo do ofertante; e este tipo de culto Deus não aceita $^{2}$. Os primeiros cristãos, reconhecendo-se como o novo Israel de Deus, vão adotar o «espiritualismo cultual», culto realizado em "espírito e verdade", não

\footnotetext{
${ }^{1}$ S. MARSILI, "A Liturgia, momento histórico da salvação", in AA.VV., A liturgia, momento histórico da salvação = Anamnesis, 1, S. Paulo: Paulinas, 1987, p. 50.

${ }^{2}$ Cf. a propósito: Sl 39,7-9; 49,14.23; 50,18-19; 68,31-32; 140,2; Is 1,10-20; Jr 7,3-11; Os 6,6; 8,11-13; Am 5,21-25 etc.
} 
mais ligado às instituições do sacerdócio ou do templo, seja o de Jerusalém ou de Garizim (Jo 4,19-26), mas que explodia do íntimo e comprometia a pessoa inteira. Num culto assim tão intenso, exigente e comprometedor, não podia haver "não participantes", pois o "tomar parte ativa" era algo de essencial.

Tomando a seguir o testemunho de alguns documentos mais representativos deste período, vejamos como se realizava em concreto a participação dos fiéis nas assembléias cultuais cristãs das origens até o $\mathrm{IV}^{\circ}$ século.

\section{O Novo Testamento}

Mateus 18,20 ("Onde dois ou três estiverem reunidos em meu nome, ali estou eu no meio deles") já nos dá um primeiro aceno sobre a assembléia cristã, constituindo-se num texto considerado fundamental para o tema da assembléia. Os exegetas, com efeito, insistem sobre o valor comunitário-eclesial desta passagem, enquadrando-a no contexto da caridade e do amor fraterno característico de todo Mt 18 e no contexto da oração comum (Mt 18,19) ${ }^{3}$.

Após a Ascensão do Senhor, os apóstolos reúnem-se na sala de cima e permanecem todos unânimes e assíduos na oração comum, com algumas mulheres, como Maria, mãe de Jesus e os irmãos dele (At 1,13s). E será nesta postura que eles, obedientes à ordem do Mestre, esperam em Jerusalém a realização da promessa do Pai (At 1,4). Em semelhante contexto de atenção e grande expectativa, Lucas nos descreve a vida da primitiva comunidade, mergulhada ainda na experiência fundamental do primeiro pentecostes cristão. No dia de Pentecostes, com efeito, pela efusão do Espírito Santo, aqueles que escutavam a palavra dos Apóstolos, se convertem e são batizados, agregando-se à comunidade (At 2,6-41). A vinda do Espírito Santo gera a comunidade de maneira consistente, pois cria o culto cristão no anúncio das maravilhas de Deus em meio ao seu povo, culto de louvor e ação de graças ao Pai por Cristo Jesus. Já nesta primeira assembléia vê-se a proclamação de Cristo Ressuscitado ocupando o primeiro lugar, sendo o Espírito de Deus seu inspirador 4 .

Os convertidos, perseveram no ensinamento dos Apóstolos, na comunhão fraterna, na fração do pão e na oração (At 2,42). Tudo tinham em comum (At 2,44). Aqui a participação nos bens materiais indica a participação solícita e intensa de todos em cada um dos atos

${ }^{3}$ Cf. A. CUVA, "Assembléia", in D. SARTORE / A. M. TRIACCA, Dicionário de Liturgia, S. Paulo: Paulinas / Paulistas, 1992, p. 95.

${ }^{4}$ Cf. J. LÉCUYER, "A Assembléia litúrgica: fundamentos bíblicos e patrísticos", Concilium 2 (1966) 7. 
da comunidade, em especial, nos atos celebrativos. Eles, na verdade, freqüentavam com assiduidade o Templo e partiam o pão pelas casas com alegria e simplicidade de coração, onde, no decurso de uma refeição fraterna, celebravam a eucaristia ${ }^{5}$. Estes textos lucanos, de grande interesse, correspondem aos primeiros testemunhos sobre a assembléia litúrgico-cristã empenhada na celebração da nova Aliança.

Todo o livro dos Atos se define como uma atuação histórica da assembléia anunciada e realizada em germe no dia de Pentecostes ${ }^{6}$. Este dia constitui o cumprimento e a "continuação escatológica da comunidade do deserto, a assembléia convocada por Deus no novo Sinai, que é a montanha de Sião, para aí receber a nova Lei e entrar na nova Aliança" 7.

Outras assembléias mencionadas no livro dos Atos são: em Jerusalém, por ocasião da instituição dos Sete $(6,2-6)$, nesta mesma cidade, reunida na casa de Maria, mãe de João (12,12); em Antioquia, por ocasião da fundação da comunidade $(11,19-26)$, do envio de Barnabé e Paulo em missão $(13,1-3)$, do retorno de ambos da missão $(14,27)$ e do envio de uma carta apostólica a esta comunidade $(15,30)$; mas, em Trôade onde os cristãos, reunidos "no primeiro dia da semana" em torno de Paulo, celebram com ele a Eucaristia (20,7-12) ${ }^{8}$. Este último texto, aliás, já sugere como a reunião da assembléia litúrgica bem cedo obedece a um preciso e significativo ritmo semanal.

Na primeira carta aos Coríntios, na medida em que propõe importantes normas práticas à comunidade, Paulo esboça uma boa reflexão sobre a assembléia litúrgica. Assim é que 1Cor 11,2 - 14,39 trata de vários problemas ligados à reunião da comunidade. Em 1Cor 11,2-16 a questão do lugar da mulher no culto é evidenciado. Neste texto de não fácil compreensão, os autores ainda discutem se Paulo estaria exigindo a aplicação do uso judaico de as mulheres rezarem com a cabeça coberta com um véu ou se ele apenas pede um comportamento feminino decente nas reuniões da comunidade, em oposição ao que sucedia no culto de Afrodite de Corinto ${ }^{9}$. Independente de tudo isso, porém, o texto é para nós de não pouca importância, na medida em que oferece um precioso testemunho sobre a participação da mulher tanto na oração pública da assembléia, como na profecia que aí se realizava.

\footnotetext{
${ }^{5}$ Cf. Ibidem, p. 8 e nota 11.

${ }^{6}$ Cf. G. RAPISARDA, "Fasi storiche dell'assemblea liturgica", in AA.VV., $L^{\prime}$ Assemblea liturgica ( ${ }^{a}$ settimana regionale di liturgia pastorale, Palermo 1978), Palermo, 1979, p. 13.

7 J. LÉCUYER, Op. cit., p. 7.

8 Cf. Ibidem, p. 8. E. MENICHELLI, "L'assemblea come segno biblico", in AA.VV., L'assemblea domenicale. Celebrare nella solidarietà, Verucchio, 1991, pp. 26-27.

${ }^{9}$ Cf. M. CARREZ, "Paolo e la chiesa di Corinto", in R.FABRIS (a cura di), Introduzione al Nuovo Testamento: 3 - Le lettere apostoliche, Roma, 1989, p. 59.
} 
Pouco antes, o Apóstolo havia lembrado a experiência da eucaristia. Nesta, participando de um único pão, o corpo de Cristo, constituímos um único corpo (1Cor 10,16-17). Pela participação no corpo e no sangue do Senhor, os cristãos formam um corpo eclesial pleno de força e de vitalidade ${ }^{10}$. Em 1Cor 11,17-34, este corpo é considerado reunido no tempo forte da assembléia para a ceia litúrgica, na qual, a práxis da inteira vida cristã se exprime com uma evidência toda particular. Todavia, as divisões no seio da comunidade negam a eficácia da morte do Senhor, que na assembléia é renovada em termos de aliança $^{11}$.

Sempre referindo-se à assembléia, Paulo segue tratando de modo amplo a questão dos carismas (1Cor 12,1-30). A multiplicidade de carismas é, sem dúvida, uma riqueza imensa para a comunidade; mas exercido no meio da assembléia eucarística com suas exigências internas de unidade, até mesmo podem pôr em perigo a união desta comunidade. A isso Paulo responde ajudado pela imagem do corpo humano, em que as diferentes funções concorrem sempre para o bem integral. De igual maneira, na comunidade eclesial, corpo de Cristo, a pluralidade de carismas contribui para a vitalidade unitária do inteiro complexo ${ }^{12}$.

O hino ao amor de 1Cor 13,1-13 insere uma interrupção no desenvolvimento de idéias entre 12,31 e 14,1. Mas, no cap. 14, Paulo retoma o discurso evocando o problema dos carismas em vista do bem comum. Tendo como preocupação básica a edificação da assembléia como um todo, o Apóstolo vai preferir aí a profecia ao dom das línguas, pois quem profetiza é capaz de edificar diretamente a assembléia, sem necessidade de oferecer ulterior interpretação ${ }^{13}$ : "Numa assembléia prefiro dizer cinco palavras com a minha inteligência, para instruir também os outros, a dizer dez mil palavras em línguas" (1Cor 14,19).

Todos estes elementos evocados nesta carta aos Corintios nos indicam a vivacidade da participação dos cristãos nesta assembléia paulina, a ponto de o Apóstolo se sentir obrigado a dar conselhos e normas em vista do aperfeiçoamento de sua organização, o que, de resto, seria dispensável, caso não houvesse aí uma grande participação.

A carta aos Hebreus, enfim, alerta os cristãos a não abandonarem as reuniões da assembléia, como alguns já faziam, mas a estarem animados, na espera do Senhor $(\mathrm{Hb} 10,25)$. E um pouco além, inspi-

${ }^{10}$ Cf. U. VANNI, “Corinzi I (Lettera ai)", in P. ROSSANO / G.RAVASI / A. GHIRLANDA (ed.) Nuovo Dizionario di Teologia Biblica, Milano, 1989, p. 300.

${ }^{11}$ Cf. Ibidem.

${ }^{12}$ Cf. Ibidem, p. 301.

${ }^{13}$ Cf. M. CARREZ, Op. cit., p. 60. 
rando-se na descrição da assembléia do Sinai, vê a assembléia litúrgica como realização da assembléia celeste $(\mathrm{Hb} 12,18-29)^{14}$.

\title{
2. A Didaqué ou Doutrina dos doze Apóstolos
}

A Didaqué ou Doutrina dos doze Apóstolos é o mais antigo documento patrístico (dos anos $80-90$ de nossa era) ${ }^{15}$ a fazer alusão a uma reunião eucarística vigiliar no domingo. Assim se expressa o cap. 14:

\begin{abstract}
"Reuni-vos no dia do Senhor para a fração do pão e agradecei (celebrai a eucaristia), depois de haverdes confessado vossos pecados, para que vosso sacrifício seja puro. Mas todo aquele que vive em discórdia com o outro, não se junte a vós antes de se ter reconciliado, a fim de que vosso sacrifício não seja profanado. Com efeito, deste sacrifício disse o Senhor: Em todo o lugar e em todo o tempo se me oferece um sacrifício puro, porque sou um grande rei - diz o Senhor - e o meu nome é admirável entre todos os povos" 16 .
\end{abstract}

Os cap. 9 e 10 desta mesma obra já haviam dado normas de como realizar a eucaristia. Aqui, no entanto, se insiste sobre a regular convocação dos fiéis, no "dia do Senhor", para em comunidade renovar a "fração do pão" e a "Eucaristia"17. Tal encontro em memória do Senhor é resposta obediente dos crentes ao apelo do "grande rei" cujo nome é maravilhoso entre os povos. E a atitude de perdão e purificação exigida dos participantes é condição indispensável à realização mesma do sacrifício ${ }^{18}$. Trata-se de um primeiro e importante aceno à reunião periódica da assembléia litúrgico-cristã que se tem notícia nesta época patrística. E as enfáticas admoestações dirigidas a cada participante quanto ao perdão e purificação, por si, são já capazes de nos indicar a importância dada ao povo da assembléia nesta "sinaxis dominical".

\section{Cartas de Santo Inácio de Antioquia}

S. Inácio de Antioquia († por volta de 110), em algumas de suas cartas fala também da importância da assembléia dos fiéis para a vida

\footnotetext{
${ }^{14}$ Cf. R. FALSINI, "Il segno e la realtà dell'assemblea liturgica", in AA.VV., L'assemblea liturgica e $i$ suoi attori $=$ Sussidi liturgico-pastorali, 14, Milano, 1966, p. 23.

${ }^{15}$ Cf. A. NOCENT, La Messa prima e dopo S. Pio $V=$ Colana Liturgica: fonte e culmine, Casale Monferrato: Piemme, 1985, p. 17.

${ }^{16}$ Didaqué ou Doutrina dos Apóstolos: Introdução, tradução e comentário de U. ZILLES = Fontes da Catequese, 1, Petrópolis: Vozes, 1970, Cap. XIV,1-3, p. 27. Edição crítica por J. P.AUDET: Didachè. Instructions des Apôtres = Études Bibliques, Paris, 1958, pp. 240-241. Cf. W. RORDORF / A. TUILIER (ed.) La doctrine des douze Apôtres. Didachè = Sources Chrétiennes, 248. Paris 1978, p. 193.

${ }_{17}$ Para esta diferença entre "fração do pão" e "Eucaristia", ver: J. P.AUDET (ed.), Op. cit., pp. 458-467.

${ }^{18}$ Cf. ibidem, p. 462.
} 
da Igreja. Nestas, a reunião da assembléia ganha um significado todo especial. Além de oferecer o pão do céu aos participantes, a reunião da assembléia manifesta a força da oração cristã, em união com o bispo e com toda a Igreja. Não freqüentar a reunião eclesial é mostrar-se cheio de orgulho diante de Deus, o qual merece o agradecimento da assembléia dos seus fiéis.

"Que ninguém se engane: quem não está junto do altar está privado do pão de Deus. Se a oração de duas pessoas juntas tem tal força, quanto mais a do bispo e de toda a Igreja. Aquele que não participa da reunião é orgulhoso e já está por si mesmo julgado, pois está escrito: "Deus resiste aos orgulhosos»" [Ad Ephes. 5,2-3].

"Esforçai-vos para vos reunir mais freqüentemente, para agradecer e louvar a Deus. Quando vos reunis com freqüência, as forças de satanás são abatidas e sua obra de ruína é dissolvida pela concórdia de vossa paz" [Ad Ephes. 13,1-2].

Na carta aos Magnésios, à exortação para que os crentes participem da assembléia cultual, une-se a preocupação, já clássica em Inácio, no sentido de manter-se a unidade da Igreja em torno do bispo e dos seus presbíteros:

"Não tenteis fazer passar por louvável coisa alguma que fizerdes sozinhos. Pelo contrário, reunidos em comum, haja uma só oração, uma só súplica, um só espírito, uma só esperança no amor, na alegria imaculada, que é Jesus Cristo: nada é melhor do que ele. Correi todos juntos como ao único templo de Deus, ao redor do único altar, em torno do único Jesus Cristo, que saiu do único Pai e que era único em si e para ele voltou" [Ad Magn. 7,1b-2].

Outro aspecto que merece ser ressaltado em Inácio é o do regozijo na assembléia dos fiéis. Assim ele pede o envio de um diácono a Antioquia, para que "vá até lá como mensageiro de Deus, a fim de me alegrar com aqueles que estão reunidos, e glorificar o Nome" [Ad Philad. 10,1]. No texto da carta aos Magnésios, acima referido, o mesmo Inácio recomenda que se reunam "na alegria imaculada" [Ad Magn. 7,1c].

\section{A Primeira Apologia de São Justino, Mártir}

Por volta do ano 150 de nossa era encontramos S. Justino e suas Duas Apologias: a Primeira endereçada por ele ao imperador Antonino Pio, e a Segunda, ao Senado Romano. Na Primeira Apologia, o autor descreve duas vezes a reunião eucarística, nos cap. 65 e $67^{19}$. Aí se

\footnotetext{
${ }^{19}$ JUSTINO DE ROMA, "I Apologia", caps. 65 e 67, in Idem, I e II Apologias, Diálogo com Trifão = Patrística, 3, S. Paulo: Paulus, 1995, pp. 81-84; PG 6, 427-432.
} 
insiste na reunião, em assembléia, de todos os que moram na cidade ou nos campos, no dia chamado "do Sol", onde são lidas as Memórias dos apóstolos e os escritos dos profetas, concluídas pelo discurso final do presidente $(67,3-4)$; segue-se a oração em pé dos participantes $(67,5)$, a ação de graças proferida pelo presidente sobre o pão e o cálice, concluída com o "Amém" comprometedor de todo o povo (65,3-4; $67,5)$, a comunhão $(65,5 ; 67,5)$ e a coleta de contribuições em favor dos pobres $(67,6)$.

Este esquema simples mas significativo de celebração, que traz consigo ainda as marcas da estrutura sinagogal de $\mathrm{culto}^{20}$, não deixa de assinalar as funções desempenhadas por parte de toda a assembléia. Com efeito, a esta cabe a oração depois da homilia, o "Amém" apropriativo no final da ação de graças, a participação à comunhão e a coleta de contribuições.

\section{A Tradição Apostólica de Hipólito de Roma}

Na Tradição Apostólica ${ }^{21}$ a participação da assembléia cristã se faz notar com grande intensidade. Na teologia de Hipólito a Igreja é profundamente carismática. A própria Tradição Apostólica foi precedida por um tratado "Sobre os carismas", escrito por Hipólito, e do qual ele

\footnotetext{
${ }^{20}$ A comparação entre esta descrição, oferecida por S. Justino, e a celebração que se realizava a cada sábado pela manhã nas sinagogas judaicas, nos mostra que os cristãos se inspiraram fortemente no desenvolver da liturgia sinagogal judaica, quando da organização inicial do seu culto eucarístico. Embora seja difícil indicar com precisão a origem da sinagoga, bem como reconstituir exatamente a celebração que aí se realizava no sábado pela manhã, podemos, porém, apontar seis elementos como fazendo parte integrante deste culto sabatino:

a) o Shema', com duas fórmulas de bênção, recitação do Deuteronômio $(6,4-9$; 11,1321) e Números (15,37-41) e bênção conclusiva;

b) a proclamação de duas leituras, uma da Torah e outra dos Profetas. Os hebreus, porém, consideravam livros proféticos, além dos que conhecemos, os de Josué, Juizes, Samuel e Reis.

c) o Midrash ou explicação (espécie de homilia), com uma aplicação espiritual para a assembléia;

d) o Canto de Salmos, em forma responsorial, com respostas do povo e "oração das 18 intenções" de ação de graças e intercessão;

e) a Bênção pronunciada pelo sacerdote, utilizando a fórmula de Aarão (Nm 6,24-26), a que todos respondiam: Amém;

f) a Coleta de bens para os pobres [Cf. A. NOCENT, "História da celebração da eucaristia" in AA.VV., A eucaristia, teologia e história da celebração = Anamnesis, 3. S. Paulo: Paulinas, 1987, pp. 210-211.

${ }^{21}$ Cf. Tradição Apostólica de Hipólito de Roma. Liturgia e catequese em Roma do século III, Tradução e notas. Introdução de M. G. NOVAK, Introdução de M. GIBIN = Fontes da Catequese, 4, Petrópolis: Vozes 1971. Edição crítica: B. BOTTE (éd.), La Tradition Apostolique de Saint Hippolyte. Essai de reconstitution = Liturgiewissenchaftliche Quellen und Forschungen, 39. Münster, Westfalen, 1989, $5^{\text {a }}$ edição.
} 
nos dá algumas notícias (cf. cap. 1 da Tradição Apostólica), mas tal tratado não chegou até nós ${ }^{22}$. A Igreja de Hipólito é, com efeito, a Igreja do Espírito Santo, onde este inspira tanto os fiéis como a hierarquia. Tal Espírito foi comunicado aos cristãos por ocasião da iniciação cristã ${ }^{23}$.

A participação na Igreja-assembléia carismática de forma concreta se faz notar, segundo a Tradição Apostólica, já na escolha do novo bispo (cap. 2.4). Mas a sua presença atuante não pára aí, manifestando-se também na celebração do sacrifício eucarístico como oferta do povo elevada a Deus através das mãos do bispo (cap. 3) ${ }^{24}$; nas refeições vespertinas da comunidade (cap. 25-30); na celebração dos sacramentos da iniciação cristã (cap. 21); na comunhão dos fiéis (cap. 22); na oração comunitária (cap. 35.41). Também o grupo dos cristãos desempenha um importante papel no recrutamento da comunidade (cap. 15) e na análise dos candidatos a serem admitidos no interior da mesma (cap. 20) ${ }^{25}$. Além disso, encontramos na Tradição Apostólica o testemunho de uma assembléia catecumenal distinta da assembléia dos fiéis ${ }^{26}$.

Já nos capítulos 35 e 41, Hipólito valoriza de maneira única o estar presente na assembléia, pois ela é o "lugar eleito" no qual claramente se realiza a ação do Espírito $^{27}$, através de uma florescente e fecunda presença: "...cada um se apressará a ir à igreja, lugar onde floresce o Espírito" ${ }^{28}$.

Quanto à participação ativa do povo cristão nas assembléias cristãs dos tempos constantinianos, Robert Cabiée ${ }^{29}$ já nos chama a atenção, afirmando serem tão numerosos os exemplos de uma rica e completa participação popular nesta época, que se torna impossível apresentar um quadro que satisfaça:

"A participação ativa do povo cristão nas assembléias ou "synaxes» marcou profundamente a vida da Igreja dos tempos constantinianos.

\footnotetext{
${ }^{22}$ Cf. B. BOTTE, "Peuple chrétien et hiérarchie dans la Tradition Apostolique' de Saint Hippolyte", in AA.VV., L'Assemblée liturgique et les différents rôles dans l'assemblée (Conférences S. Serge, $23^{a}$ semaine d'études liturgiques, Paris 1976) = Bibliotheca 'Ephemerides Liturgicae', 'Subsidia', 9. Roma, 1977, p. 79.

${ }^{23}$ Cf. ibidem, p. 80.

${ }^{24}$ Cf. ibidem.

${ }^{25}$ Cf. ibidem, p. 81.

${ }^{26}$ Cf. G. RAPISARDA, Op. cit., p. 16.

${ }^{27}$ Cf. S. DI CRISTINA, "Il popolo dell'assemblea nei Padri", in AA.VV., L'Assemblea Liturgica ( $1^{\text {a }}$ settimana regionale di liturgia pastorale, Palermo 1978), Palermo, 1979, p. 80.

${ }^{28}$ B. BOTTE (ed.), Op. cit. p. 83; cf. também ibidem, p. 89.

${ }^{29}$ Cf. R. CABIÉ, "A Eucaristia", in A. G. MARTIMORT (ed.), A Igreja em oração. Introdução à liturgia, vol. 2, Petrópolis: Vozes, 1989.
} 
Permaneceu sendo elemento importante nos séculos seguintes, mesmo se algumas funções tendessem a ser tomadas por grupos de pessoas mais experimentadas, como as scholae cantorum. Suas manifestações são, algumas vezes, exageradas, a tal ponto que as homilias dos $\mathrm{Pa}$ dres, principalmente de $S$. João Crisóstomo, deverão apelar para a ordem e disciplina no decorrer das celebrações" ${ }^{30}$.

\section{O diário de viagem de Egéria}

O maior exemplo desta ampla participação, porém, nos é dado por Egéria no seu diário de viagem ${ }^{31}$, quando narra a vida litúrgica da comunidade cristã de Jerusalém no final do $\mathrm{IV}^{\mathrm{o}}$ século ${ }^{32}$.

A descrição cheia de entusiasmo oferecida por Egéria toca-nos profundamente, por revelar um alto grau de participação popular nas ações litúrgicas. De fato, é impressionante o tempo dedicado ao culto por estes cristãos de Jerusalém nesta época. Antes que o dia amanheça, ei-los já na igreja para os ofícios litúrgicos matinais, o que se repetia três ou quatro vezes ao longo da jornada. Já no domingo dedicavam quase todo o dia às santas celebrações, tornando-o exatamente aquilo que o termo exprime: o dia do Senhor. E o desejo de que todos participem ativamente de cada ato celebrado vem a cada momento indicado na descrição de Egéria. É o caso, por exemplo, quando ela

\footnotetext{
${ }^{30}$ Ibidem, pp. 59-60.

${ }^{31}$ Peregrinação de Etéria, introdução, tradução e notas por M. G. NOVAK e comentário de A. BECKHAEUSER = Fontes da Catequese, 6, Petrópolis: Vozes, 1971. Edições críticas: a) A. FRANCESCHINI / R.WEBER (ed.) Itinerarium Egeriae = Corpus Christianorum, Series Latina, 175, Turnhout: Brepols, 1965, pp. 67-90; b) ÉGÉRIE, Journal de Voyage. (Itinéraire), Introduction, texte critique, traduction et notes, index et cartes par P.MARAVAL = Sources Chrétiennes, 296. Paris: 1982, pp. 235-319.

32 Apresentamos abaixo um precioso resumo desta intensa e consciente participação da assembléia litúrgica nos atos de culto desenrolados na Cidade Santa por esta época, tal como nos descreve Egéria e nos sintetiza R. CABIÉ, em "A Eucaristia", Op. cit., p. 68: "... o povo dirigindo-se a igrejas iluminadas, de manhã e à tarde, tochas acesas, monges e virgens cantando hinos, antífonas e salmos. Vê-se aí o cortejo dos ministros e de todo o clero das basílicas escoltando o bispo que, por sua vez, entra para celebrar os santos mistérios. Aí estão as crianças fazendo muito ruído e cantando o Kyrie eleison e os leitores proclamando passagens da Escritura sempre apropriadas ao dia e ao lugar. São percebidos gritos, gemidos e lágrimas dos participantes quando se lê o relato da paixão e ressurreição do Senhor. Enquanto o bispo faz a homilia, em grego, um sacerdote vai traduzindo quase que simultaneamente para o siríaco e, irmãos e irmãs, na assembléia, dão explicações, em latim, aos que só entendiam esta língua. O povo se levanta para a comunhão. Todos são atentos às monições dos diáconos que dirigem a oração, convidando-os a se inclinar para receber a bênção do presidente, ou despedindo os fiéis, sem esquecer de convocá-los para a próxima reunião. Homens e mulheres de todas as idades seguem em procissão, partindo de um dos lugares santos até a igreja onde será celebrada a eucaristia. Caminham lentamente, se o percurso é longo, para não cansar a multidão. Estamos diante de um caso especial, porque Jerusalém é uma cidade de peregrinações, mas participações análogas, com certas características diferentes, são encontradas em Antioquia, Hipona ou Arles".
} 
assinala que a homilia do bispo sempre tinha tradução simultânea a várias línguas, para que todos a entendessem, também quando nos descreve as inúmeras monições orientativas proferidas pelo diácono ao longo da inteira celebração ou ainda quando da narração das inúmeras procissões em direção às várias estações litúrgicas de Jerusalém, nas quais se comemorava este ou aquele episódio da História Sagrada, elemento peculiar da liturgia desta cidade, única no mundo em que as celebrações e suas leituras são sempre adaptadas ao tempo e ao lugar (cf. 25,10;29,2.5; 31,1;35,4; 47,5) ${ }^{33}$.

$\mathrm{O}$ prestígio e o esplendor litúrgico de Jerusalém no final do $\mathrm{IV}^{\circ}$ século, longe de afastar o povo da liturgia ou relegá-lo a uma função secundária na mesma, encontra a sua mais forte expressão exatamente na presença e atuação da assembléia unida para a celebração. E isso é prova de que esplendor celebrativo e intensificação litúrgica não são de maneira nenhuma sinônimos de passividade do povo na liturgia e nem sempre levam à incompreensão ritual. Para isso basta organizar uma celebração rica nos sinais e profunda no sentido, mas que seja ao mesmo tempo significativa e ligada à vida dos que dela tomam parte. Talvez neste pormenor a liturgia de Jerusalém do $\mathrm{IV}^{\circ}$ século, aqui relatada por Egéria, tenha muito o que ensinar às nossas liturgias hoje. Tanto mais que não parece tratar-se de uma experiência exclusiva da cidade de Jerusalém destes tempos, pois, conforme ainda enfatiza Egéria, algo de muito semelhante encontra-se ainda em outros lugares por esta mesma época.

\section{Outros testemunhos de participação ativa na assembléia}

Todos estes exemplos nos dão prova da grande importância dada pelos primeiros cristãos à assembléia cultual e de como se realizava aí a sua intensa participação. Muitas outras provas podem ainda ser aqui evocadas, desde os inícios da Igreja até épocas um pouco mais tardias. Um dos elementos mais significativos da assembléia é, sem dúvida, a presença de todos, a união no amor, na caridade, o elevar os louvores a Deus numa só voz, numa só ação de graças, como bem nos ilustra

\footnotetext{
${ }^{33}$ Peregrinação de Etéria,..., Op. cit., p. 26, do comentário de A. BECKHAEUSER: "Notemos que no culto de Jerusalém se realizava o engajamento do homem todo: procissões, estações, jejuns, gestos. Tudo isso recebia seu significado através das leituras da Sagrada Escritura, adaptadas aos tempos e lugares. Seguiam-se as orações compreendidas como resposta atual do povo e aplicação dos ensinamentos à vida prática. É de se notar uma grande familiaridade com a Sagrada Escritura. Desta forma o culto comunitário era realmente expressão da fé, da piedade e do amor dos cristãos. Rezavase em comum, e rezava-se um pelo outro. As intenções eram formuladas pelo Bispo ou pelo Diácono. Tal familiaridade com a Bíblia, aplicada à vida, a união na oração e a Celebração da Eucaristia constituíam uma bela expressão da vida da Igreja de Jerusalém".
} 
Clemente de Roma na carta aos Coríntios: "Também nós, na concórdia, unidos na mesma consciência, como uma só boca, chamemos a ele com insistência, a fim de que tenhamos parte nas suas grandes $e$ magnificas promessas" ${ }^{34}$. Interessante é ainda observar o testemunho de um pagão sobre a reunião dos fiéis, como encontramos em Plínio, o Jovem, em sua carta a Trajano (escrita pelo ano 112), na qual dá notícia sobre a assembléia cristã: Costumam reunir-se habitualmente num dia determinado, antes da aurora, e recitar entre eles em dois coros uma invocação a Cristo, considerando-o um deus ${ }^{35}$.

Em outro escrito, a presença na assembléia dos fiéis é exigida e reclamada através de preciosos argumentos: para não dilacerar o corpo uno do Senhor e não antepor nada de temporal à palavra de Deus. É como se expressa a Didascália, documento cristão da metade do século III (c. 250):

"Porque sois membros de Cristo, não disperseis a Igreja não reunindo-vos; de fato, porque tendes em Cristo o vosso chefe presente e em comunhão convosco, segundo a sua promessa, não negligencieis e não priveis o Salvador de seus membros, não dilacereis e não disperseis o seu corpo nem queirais antepor à palavra de Deus as necessidades da vossa vida temporal, mas no dia de domingo, ponde de parte todas as coisas, apressais em ir à Igreja. De fato, qual justificação poderá apresentar a Deus quem não se reúne nesse mesmo dia em assembléia para escutar a palavra de salvação e nutrir-se (do alimento divino que dura em eterno)?" ${ }^{36}$.

É bem verdade que no Concílio de Elvira (c. 300/302 ou 306/313) já encontramos um cânon prescrevendo a presença do cristão na igreja no domingo, sinal de que aqui e ali já se manifestava a falta de alguns na assembléia dominical do Senhor: "Se alguém que esteja em uma cidade não vai na Igreja por três domingos, seja excluído por um pouco de tempo, de modo que fique evidente que foi punido" ${ }^{37}$. Tal situação, porém, não parece ser normal nesta época, pois sabemos que mesmo apesar das muitas perseguições, das calúnias e dificuldades de toda ordem, muitos cristãos jamais abandonaram a reunião da assembléia, onde participavam com todo ardor, exatamente porque ela se constituía na razão última das suas existências.

\footnotetext{
${ }^{34}$ S. CLEMENTE, Ad Cor. 34,7; cf. S. INÁCIO, Ad Ephes. 4,1-2.

35 PLÍNIO, O JOVEM, Carta a Trajano 10, 96, 7, citação em W. RORDORF, Sabato e domenica nella Chiesa antica (Traditio Christiana). Torino: Società editrice internazionale, 1979, pp. 136-137.

${ }^{36}$ Didascalia, II, 59, 2-3; cf. citação em W. RORDORF, Op. cit., pp. 168-169.

${ }^{37}$ Concílio de Elvira, Cânon 21, sobre aqueles que são pouco zelantes em ir à Igreja; cf. citação em W. RORDORF, Op. cit., pp. 176-177.
} 
Assim nos impressionam os mártires da Abitínia, na África dos inícios do $\mathrm{IV}^{\circ}$ século (c. 304), quando interrogados pelo governador que os queria proibir de participar da reunião da assembléia, sob pena de os martirizar, respondem sem nenhum constrangimento: "a ceia do Senhor não pode ser abandonada" e, "sem participar da ceia dominical do Senhor, não podemos viver" (sine dominico non possumus) ${ }^{38}$.

Elemento que, sem dúvida, concorria para a intensificação da participação no culto, era o fato de não existirem, nos três primeiros séculos cristãos, livros litúrgicos propriamente ditos, a não ser o texto da Bíblia. A liturgia desta época, permanecendo sempre fiel à tradição nos seus elementos essenciais, era em muito aberta à livre criatividade e quem presidia a celebração, elevava o seu louvor conforme a sua capacidade, adaptando-o ao público presente. Nesse sentido é que, quando, na sua Tradição Apostólica, Hipólito oferece ao novo bispo para o dia de sua ordenação um esquema de oração eucarística, o qual concorreu a formar a nossa muito conhecida "Oração Eucarística n II", diz que não é necessário que o bispo "pronuncie literalmente as palavras transcritas, como que precisando esforçar-se para sabê-las e usá-las de cor, mas cada um reze segundo suas capacidades. Se alguém é capaz de rezar longamente e com solenidade, está bem. Mas se pronuncia uma oração curta, não seja impedido de fazê-lo, contanto que reze uma oração de sã ortodoxia" ${ }^{39}$.

Ainda tantas outras provas nos dão idéia da centralidade e do significado da assembléia cultual dos fiéis na vida da Igreja primitiva. Tais exemplos nos fazem refletir sobre a necessidade de promovermos e bem valorizarmos também hoje a santa reunião dos cristãos convocados pela Palavra de Deus e em resposta ao seu apelo, na elevação do mesmo culto ao Pai e na obtenção da graça que, pelo Filho Mediador e na força do Espírito, até nós não cessa de chegar.

\footnotetext{
${ }^{38}$ Durante a perseguição romana de Diocleciano, um grupo de cristãos foi surpreendido e preso enquanto celebrava a missa dominical. Os Atos destes mártires nos fornecem a descrição de cada interrogatório a que foram submetidos. Todos respondem ao pró-consul do mesmo modo e são, a seguir, martirizados. Os Atos dos mártires da África nos dão, pois, um testemunho impressionante da importância vital que davam à eucaristia dominical. Cf. citação em W.RORDORF, Op. cit., pp. 176-177; cf. A. PISTOIA, "L'assemblea come soggetto della celebrazione", Rivista Liturgica 72 (1985) 431.

39 B. BOTTE (éd.), La Tradition Apostolique ...., Op. cit., cap. 9, pp. 28-29. A respeito desta espontaneidade litúrgica na Igreja das origens, ver J. A. JUNGMANN, El sacrificio de la Misa: Tratado historico liturgico (Missarum sollemnia) = BAC, 68. Madrid: Católica, 1963, pp. 49-51; J. PINEL, "Liturgias locais antigas (Origem e evolução)", in D. SARTORE / A. M. TRIACCA, Dicionário de Liturgia, São Paulo: Paulinas / Paulistas, 1992, pp. 670-676; I. SCICOLONE, "Livros litúrgicos" in D. SARTORE / A. M. TRIACCA, Idem, pp. 684-686.
} 


\section{Decadência da participação na assembléia ${ }^{40}$}

No que se refere a Roma, tudo indica que a participação do povo reunido em assembléia cristã se exprime pelos séculos IV e V na missa "estacional" do bispo, o qual reúne em torno de si para a Eucaristia todo o clero e representantes dos fiéis das várias zonas da cidade ${ }^{41}$. Não obstante tudo isso, estes mesmos séculos IV e V já começam a dar leves sinais de decadência no nível de participação da assembléia do povo, conforme já nos informa Cipriano Vagaggini ${ }^{42}$, o que se agravará muitíssimo na Idade Média.

No fim do Vo século, o papa Gelásio (492-496), talvez influenciado pelo costume da comunidade grega de Roma, transforma a Oração Universal ou dos Fiéis, que era um importante meio de participação popular na liturgia, numa litania cujas intenções não só serão propostas pelo diácono, como também a súplica que a segue: Kyrie ou Christe eleison. Pouco depois esta oração é transferida para o início da celebração, antes do Glória ${ }^{43}$, e acabará por perder as intenções, permanecendo apenas a súplica. Assim se retirou das mãos dos fiéis um de seus elementos mais próprios e tradicionais (já referida por S. Justino na Primeira Apologia), fonte de grande participação na celebração e de resposta orante às leituras escutadas.

Mas se tomamos um documento da importância do Ordo Romanus I ${ }^{44}$, que oferece uma extensa descrição da missa romana presidida pelo papa, já nos encontramos diante de um cerimonial grandioso e intrincado, que exige os serviços da Schola cantorum e de um grande número de ministros devidamente treinados ${ }^{45}$. Em um tal ambiente cresce a pompa cerimonial, mas decresce a participação dos fiéis, relegados agora a meros espectadores de um ritual espetacular e estranho $^{46}$. Daí a se chegar a uma celebração concentrada apenas na pessoa do sacerdote celebrante, será apenas um pequeno passo. E tal

\footnotetext{
${ }^{40}$ Ver sobre o assunto: G. RAPISARDA, Fasi storiche ..., Op. cit., pp. 16-18; S. MARSILI,

"A Liturgia ...", Op. cit., pp. 63-102.

${ }^{41}$ Cf. R. CABIÉ, "A Eucaristia ...", Op. cit., p. 60: "A palavra statio designa uma assembléia convocada com antecedência para se realizar em dia e edifício determinados".

${ }^{42}$ Cf. C. VAGAGGINI, Il senso teologico della liturgia. Saggio di liturgia teologica generale,$=$ Theologica, 17. Roma, 1965, p. 227.

${ }^{43}$ Cf. A. NOCENT, La Messa ..., Op. cit., p. 28; J. A. JUNGMANN, El sacrificio de la Misa ..., Op. cit., pp. 80-81.

${ }^{44}$ M. ANDRIEU, Les Ordines Romani du haut Moyen Âge, Ordo I, vol. 2. Louvain, 1960 pp. 67-108. O Ordo Romano I é do VIII séc., mas testemunha usos bem anteriores a esta data, conforme afirma A. NOCENT, La Messa ..., Op. cit., p. 27, nota 27.

${ }^{45}$ Uma boa descrição do culto estacional romano do séc. VII, tendo por base o Ordo Romano I, nos é dada por J. A. JUNGMANN, El sacrificio de la Misa ..., Op. cit., pp. 90-98.

${ }^{46}$ Cf. S. MARSILI, “A Liturgia ... “, Op. cit., pp. 68-70.
} 
fase vai ser marcada pelo aparecimento dos livros litúrgicos plenários. Com efeito, em tempos próximos ao ano mil e por motivos funcionais, vários livros litúrgicos começam a se fundir, colocando-se num só livro plenário todos os elementos que servem a uma celebração. Assim vão surgir em primeiro lugar o Pontifical, com fórmulas e ritos para a celebração do bispo; a seguir, pelos fins do século X, o Missal, com todo o necessário para a celebração da eucaristia: ordo da missa, orações, antífonas, leituras; a partir do século XII, o Ritual, como livro paralelo ao Pontifical, mas destinado aos sacerdotes e contendo os ritos realizados por este; também o Breviário, lançado após o ano mil, que recolhia tudo para a celebração da Liturgia das Horas ${ }^{47}$. "Este é também o momento em que o sentido do exercício do sacerdócio batismal de cada cristão desaparece em favor do exclusivo valor dado ao sacerdócio ordenado" ${ }^{48}$.

A partir da época medieval o sentido da liturgia, a eucarística em especial, como uma ação da inteira comunidade começa a dar lugar a uma série de anomalias litúrgicas, que aumentam à medida em que também avança na Igreja a ignorância litúrgica. Exemplos destes abusos são as "Apologias" 49, que intimamente relacionadas com a disciplina das "Comutações", se inserem com timidez na missa a partir do século $\mathrm{IX}^{\circ}$, mas se proliferam mesmo no $\mathrm{X}^{\circ}$ e $\mathrm{XI}^{\circ}$ séculos. Apologias eram orações para pedir perdão, introduzidas na missa celebradas pelos vivos e pelos mortos. Através delas o padre implorava a piedade do Senhor para si próprio, para os que tinham encomendado a missa ou também para aqueles em favor de quem ela era celebrada. Em determinadas missas as apologias eram numerosíssimas, dominando quase todo o rito. Elas eram encontradas em momentos como das ofertas, e também durante o Sanctus. Dirigiam-se a Cristo, à Trindade Santa etc. Conservadas no Missal de S. Pio V, algumas ainda permanecem no Missal atual, como as duas orações à escolha antes da comunhão ${ }^{50}$.

A disciplina da "Comutação" estará ligada tanto ao sacramento da penitência, quanto à eucaristia. Como as satisfações impostas pelos pecados confessados eram altas, encontrava-se uma maneira de realizálas, mesmo que de forma bastante estranha. Assim se podia usar os serviços de outros que, mediante pagamento, cumpriam a penitência

${ }^{47}$ Cf. I. SCICOLONE, "Livros litúrgicos" ..., Op.cit., pp. 687-689.

${ }^{48}$ A. NOCENT, La Messa ..., Op. cit., p. 33.

${ }^{49}$ Cf. A. NOCENT, "Les apologies dans la célébration eucharistique", in PISTOIA A. / TRIACCA A. M. (ed.) Liturgie et rémission des péchés: Conférences Saint-Serge. XXe Semaine d'études liturgiques = Bibliotheca 'Ephemerides Liturgicae', 'Subsidia', 3, Roma: Liturgiche, 1975, pp. 179-196.

${ }^{50}$ Cf. A. NOCENT, "O sacramento da penitência e da reconciliação", in AA.VV., Os sacramentos, teologia e história da celebração = Anamnesis, 4, São Paulo: Paulinas, 1989, pp. 191-192. 
em nome do pecador. Mas a penitência também podia ser comutada, isto é, convertida em outra obrigação. Exemplo: no lugar de dois dias de jejum rezava-se 100 salmos ou se fazia 100 genuflexões ou se recitava sete cantos da Bíblia; em vez de um ano de jejum, um mês de severíssimas penitências corporais, até conduzir ao perigo de morte etc. Mas interessa-nos, mais que tudo, o fato de que se comutava a satisfação imposta pela celebração de missas. Um número determinado dessas podia substituir sem problemas muitas penitências. E isso com o perigo real de suprimir-se também todo esforço ascético em vista da emenda dos pecados, que era a razão última de qualquer satisfação.

Constituíam ainda uma séria aberração, sempre na Idade Média, as assim chamadas missa sicca e missa bifaciata, tri-quatrifaciata 51, "que eram duas formas diversas de eludir a proibição de celebrar mais missas por outros tantos estipêndios" ${ }^{2}$. Como o padre só podia receber uma espórtula de missa por dia sem incorrer no erro da simonia, inventou-se outros tipos de celebração que tinham aparência de missa, mas não eram, e assim garantiam outras espórtulas. A missa sicca era uma delas. Consistia no padre repetir todos os formulários da missa, omitindo-se apenas a oração sobre as oferendas, o cânon e a comunhão. Em alguns dias aconselhava-se mesmo, para não elevar o pão não consagrado, de elevar-se a relíquia de um qualquer santo ${ }^{53}$.

Já a missa bi-tri-quatrifacciata combinava em uma só, várias missas, possibilitando sempre a obtenção de vários estipêndios. Ela se realizava assim: começava-se de modo normal a missa do início, indo até o ofertório, depois voltava-se ao início e chegava-se até o ofertório, e outra vez do início até o ofertório, tantas vezes quantas missas se quisesse celebrar. Depois fazia-se um só ofertório com um só cânon e uma só comunhão. E a seguir rezava-se da oração depois da comunhão até o final tantas vezes quantas se havia feito na primeira parte da missa. Deste modo, na estrutura de uma só missa, eram ditas duas, três, quatro ou mais missas. Simulava-se, assim, um verdadeiro espetáculo ${ }^{54}$.

A própria disposição arquitetônica das igrejas no período vai contribuir para esta situação, pois ajudará ainda mais a separar o povo do local onde se passa a cena litúrgica, ou seja, o presbitério, agora posto em lugar elevado e distante. Aí será criado um amplo espaço em torno

\footnotetext{
${ }^{51}$ S. MARSILI, “A Liturgia ... “, Op. cit., pp. 71-73; Idem, “Teologia da celebração da eucaristia", in AA.VV., A eucaristia, teologia e história da celebração = Anamnesis, 3.S. Paulo: Paulinas, 1987, pp. 97-99.

52 Ibidem, p. 71.

53 Cf. ibidem, pp. 71-72.

${ }^{54}$ Cf. ibidem, p. 72.
} 
e diante do altar, ideal para a realização de uma liturgia solene, pomposa e incompreensível, à qual o povo assistirá lá de baixo e de longe, como a um espetáculo ${ }^{55}$. Isso reforçará a separação entre aquele que realiza a liturgia, o clero, agora sacralizado, e o que assiste a liturgia, a massa do povo. Quase nada restará, pois, daquele rito espiritual que tanto qualificou o cristianismo nas suas origens, mostrando a distinção entre o culto do Novo Povo da Nova Aliança e o culto do Antigo Testamento. É como se este último culto houvesse invadido o primeiro, vencendo afinal no seu aspecto de juridismo-exteriorismo litúrgico ${ }^{56}$.

Mas diante de uma tão grave situação litúrgica, vão surgir, ainda durante a Idade Média, duas tentativas em dois planos diferentes, que tentarão de qualquer forma manter vivo o sentido religioso-cultual cristão. Tais tentativas serão a explicação alegórica da liturgia (não confundir, porém, com a figura literária da alegoria) e o devocionismo.

A explicação alegórica da liturgia buscou estranhos significados para pessoas, gestos e coisas, sempre na tentativa de conservar uma certa relação entre a liturgia e o povo: "Assim, por exemplo, na missa, para Amalário (século IX), «O cálice é o sepulcro do Senhor; o celebrante é José de Arimatéia, e o arcediago é Nicodemos, enquanto sepultadores de Cristo; os diáconos, que estão inclinados atrás do celebrante, são os apóstolos que na paixão do Senhor procuravam apoucar-se e ocultarse; os subdiáconos, que diante do celebrante estão em posição ereta, são as mulheres que com liberdade estavam junto da Cruz». Depois que se perdeu o sentido do rito e do valor funcional das suas partes, também o «símbolo» fundamental da missa, o ser, isto é, sinal sacramental da paixão do Senhor, foi dividido arbitrariamente em outras tantas visões alegóricas da paixão de Cristo" ${ }^{57}$.

Já o devocionismo apresentava-se como um verdadeiro e próprio substituto de uma liturgia à qual o povo já não compreendia mais e de quem estava de fato distanciado. Profundamente vinculado ao surgimento de corporações religiosas, o devocionismo manifestar-se-á como movimento religioso leigo que por hábito dispensava a presença e atuação do sacerdote. Tendo por objeto os mistérios de Cristo, a Virgem Maria e os santos, exatamente como a liturgia, o devocionismo se distanciará desta, pois o fundamental aqui não será o acolher a

\footnotetext{
55 “Com efeito, isto é agora a Liturgia: um «espetáculo» religioso, a que o povo assiste unindo estranhamente a fé mais profunda a atitudes que conciliam ao mesmo tempo, a mundanidade mais desenfreada e a devoção mais supersticiosa, que muitas vezes se aproxima claramente da "magia», como se pode notar pelo fato de que os mesmos pregadores apelam freqüentemente para as "palavras de encantamento», usadas, por exemplo, pelos encantadores de serpentes, para explicar a eficácia das palavras do sacerdote na missa" (ibidem, pp. 72-73).

${ }^{56}$ Cf. ibidem, pp. 68-71.

57 Ibidem, p. 75.
} 
salvação de Deus em Cristo, mas o oferecer a Deus a gratidão, a admiração, a penitência como meios de obtenção da salvação ${ }^{58}$. Assim, quanto maior e mais intensa a devoção, mais intensos e duradouros os frutos que ela pode dispensar ao devoto.

Sem dúvida estas duas tentativas não conseguem resolver a situação de crise por que passava a liturgia. Mas a busca de solução não se extinguirá. Assim é que o início da Época Moderna, ante o falimento das tentativas anteriores de culto, marcará um rompimento total com todas as suas formas externas e a adoção de uma nova corrente, o interiorismo religioso ou "devotio moderna". Trata-se de um movimento de reforma espiritualista que tentará injetar meditação no culto e que se desmembrará em duas correntes: uma ortodoxa, que não pretende abolir a liturgia, mas impregná-la de meditação; outra, que diante de sua incapacidade de tornar-se culto espiritual, abolirá a liturgia para dar importância única à palavra de Deus, e será o protestantismo ${ }^{59}$.

Desta maneira se concluirá a Idade Média e se iniciará a Moderna, sem ter oferecido uma resposta significativa à importante questão cultual cristã, sobretudo no que se refere à participação do povo na liturgia. Claro que, sem um exato conhecimento do que vinha a ser de fato a liturgia, tornava-se muito difícil promover qualquer tipo de participação litúrgica capaz de responder às reais aspirações dos fiéis cristãos. Estarão, assim, abertas as portas para a grande Reforma Protestante e para a reação católica a esta, organizada, em especial, pela realização do famoso Concílio de Trento.

\section{SEGUNDA PARTE}

\section{A participação do povo na Eucaristia: do Concílio de Trento ao Vaticano II}

\section{Da situação anterior a 1570 à convocação do Concílio Tridentino}

Lançando um olhar de conjunto à global situação litúrgica da Igreja no longo período que se estende das suas origens ao momento do Concílio Tridentino, observamos a passagem de uma época inicial, de fundamental importância para a participação na assembléia dos fiéis, a uma outra em que esta participação se faz cada vez mais débil e

${ }^{58}$ Cf. ibidem, pp. 77-80.

${ }^{59}$ Cf. ibidem, pp. 80-81. 
insignificante, quase inexistente ${ }^{60}$. A Igreja, com efeito, organizada a partir da experiência pentecostal, tem na participação de todos na assembléia de culto o seu elemento mais básico e evidente. Mas à medida em que esta comunidade se afasta temporalmente de sua matriz apostólica, e adentra no período medieval, se adverte um progressivo esquecimento da assembléia litúrgica, com o conseqüente esfriamento da participação do povo cristão nos atos celebrados.

Tempos depois nos encontramos diante de uma celebração toda concentrada no sacerdote celebrante. "Este é também o momento em que o senso do exercício do sacerdócio batismal de cada cristão desaparece em favor do relevo exclusivo dado ao sacerdócio ordenado" ${ }^{61}$.

Vemos perder-se aquela natureza litúrgico-comunitária da missa, lentamente obscurecida a partir do $\mathrm{IV}^{\circ}$ e $\mathrm{V}^{\circ}$ século, mas sobretudo na Idade Média ocidental ${ }^{62}$. Apoiando-se no The shape of the liturgy, de G.Dix $^{63}$, e no Missarum Sollemnia, de J.A. Jungmann, C. Vagaggini ${ }^{4}$ constata como, na sua própria natureza e estrutura ritual antiga, a missa aparece essencialmente como ação da comunidade eclesial inteira, em especial aquela presente hic et nunc. Assim não se podia conceber antigamente que alguns membros da comunidade se apresentassem à missa como espectadores ou simples ouvintes, ou ainda ocupados com pensamentos e orações particulares, sem referência ou só de longe referidos à ação litúrgica que ali se realizava ${ }^{65}$.

De início as orações na missa eram ditas em voz alta e para todos os presentes, numa língua compreendida por todos, estando o povo reunido em torno à mesa eucarística. E na celebração todos comunga-

\footnotetext{
${ }^{60}$ Naturalmente é muito difícil abranger com um só golpe de vista, tão vasto a ponto de abraçar tantos séculos, sem incorrer em erros históricos e reduções interpretativas. A nós, porém, interessa apenas mostrar com poucas palavras a tendência geral dos séculos que antecederam, margearam e levaram ao Concílio de Trento. Todavia, continua problemático, como já foi demonstrado, determinar com exatidão a situação litúrgica da Igreja, mesmo se nos restringimos ao período do declínio da Idade Média ao início da época moderna - período que de perto interessa ao Tridentino - seja pela variação da situação em cada lugar, seja por uma identificável evolução na prática religiosa dos cristãos nesta época (Cf. G. ALBERIGO, "Dalla uniformità liturgica del Concilio di Trento al pluralismo del Vaticano II", Rivista Liturgica 69 (1982) 604).

${ }^{61}$ A. NOCENT, La Messa ..., Op. cit., p. 33.

${ }^{62}$ R. FALSINI, "Il segno ...", Op. cit., p. 28: "A partir do século IX o declínio da assembléia dominical prossegue ininterrupto: primeiro são as igrejas dos feudatários e depois as das Ordens Mendicantes, que levam ao fracionamento das assembléias locais. De bem pouco valerão as advertências a freqüentar a própria igreja, norma que será retomada também pelo Concílio de Trento. Não se fala mais de assembléia, mas do dever de assistir a missa. À visão teológica sucede a norma moral de satisfazer o preceito".

${ }_{63}$ G. DIX, The Shape of the Liturgy, edição revista por P. V. MARSHALL, London, 1981.

${ }^{64}$ C. VAGAGGINI, Il senso teologico ..., Op. cit., pp. 277-284.

${ }^{65} \mathrm{Cf}$. ibidem.
} 
vam, pois a comunhão era, em sentido profundo, o rito de participação de cada fiel no banquete sacrifical. Apesar de se tratar de uma ação comunitária, cada um tinha a sua função: era ação de todos, mas exercida pelos vários membros da comunidade de modo diversificado.

A seguir, porém, de modo pronunciado, na época medieval este sentido da missa como ação de toda a comunidade começa a ser substituído por expressões rituais e rubricistas, verdadeiras anomalias sem nenhum apoio na tradição mais antiga ${ }^{66}$.

Todavia, importa observar aqui, nem todas as manifestações litúrgicas desta época podiam ser consideradas desordens ou abusos. Muitos elementos não passavam de manifestações de um legítimo pluralismo das liturgias locais, variações estas que as condições próprias do tempo que se seguiu à celebração do Tridentino, com um excessivo zelo farão quase desaparecer da Igreja romana. Na maioria das vezes, a variedade e a desordem vinham de tal forma unidas na concreta liturgia de uma Igreja local, que se tornava difícil determinar onde iniciava uma e terminava outra ${ }^{67}$. Daí que muitas sugestões de reforma propostas no início do século XVI, portanto, às vésperas da convocação do Concílio de Trento, apresentavam uma inspiração unitária $^{68}$, embora não se possa atribuir àqueles que as sustentavam a intenção de chegar à rígida uniformização que se estabeleceu no tempo imediatamente seguinte ao Tridentino ${ }^{69}$.

É desta forma que chegamos ao Concílio de Trento $^{70}$. No que se refere de modo especial à eucaristia, há em Trento muita preocupação, o que é compreensível. Os abusos centrados na celebração, ligados a uma grande ignorância teológico-bíblica, uma intensa procura por parte do povo de elementos milagrosos e prodigiosos na Missa e os duros ataques dos reformadores protestantes a esses mesmos abusos, colocavam em risco a própria concepção do sacramento. Além disso, faltava unidade ritual, devido à grande diversidade que se foi introduzindo no modo de celebrar a eucaristia ${ }^{71}$. Era necessário, pois, que o Concílio

\footnotetext{
${ }^{66}$ Cf. ibidem.

${ }^{67}$ Cf. G. ALBERIGO, "Dalla uniformità ...", Op. cit., p. 605.

68 "Desde Erasmo de Rotterdam a Querini e Giustiniani, aos memoriais redigidos na vigília do concílio de Trento e, depois, durante o seu acontecimento, a reforma litúrgica foi impostada em prospectiva unitária" (Ibidem).

${ }^{69}$ Cf. ibidem. Para uma apresentação crítica suficientemente bem documentada desta época, veja: H. JEDIN, Storia del Concilio di Trento, vol. I, Brescia, 1987, $3^{a}$ ed.

${ }_{70}$ Para o assunto, ver em especial: H. JEDIN, Storia del Concilio di Trento, vol. II, Brescia, 1962; vol. III, Brescia, 1982, 2a ed.; vol. IV/2, Brescia, 1981, pp. 344-348; H. SCHMIDT, Liturgie et langue vulgaire. Le problème de la langue vulgaire chez les premiers Réformateurs et au Concile de Trente, Romae 1950; G.ALBERIGO, I vescovi italiani al concilio di Trento (1545-1547), Firenze, 1959.

${ }^{71}$ Cf. P. JOUNEL, Les rites de la Messe en 1965. (Ritus servandus-De defectibus-Ordo missæ $)=$ Les premières étapes de la réforme liturgique, II, Paris, 1965, p.10.
} 
agisse rápido, buscando cicatrizar tanto as feridas provocadas pelas anomalias como, e mais que tudo, as abertas pelas inexoráveis críticas dos reformadores ${ }^{72}$.

Apesar de toda a grave situação, o Concílio não demonstrou comportamento intransigente, como por vezes se faz acreditar, mas alimentou a procura de uma reforma litúrgica equilibrada ${ }^{73}$. Mais que dar uma visão de conjunto da liturgia, interessava ao Tridentino responder às denúncias dos protestantes e aos abusos introduzidos no culto litúrgico cristão. O Concílio, porém, se aproximava de seu fim sem ter analisado ainda importantes problemas abertos, como o da revisão dos livros litúrgicos, e em especial, o Missal e o Breviário. Aqui a falta de tempo se juntava à presença na aula conciliar de orientações e tendências diversas, que impediram o enunciado de critérios para uma tal revisão ${ }^{74}$. Assim, a XXV a e última sessão do Concílio passou ao Pontífice romano tal encargo ${ }^{75}$. Mas isto não significa que $o$ Concílio de Trento tenha elaborado uma diretiva unitária e uniforme em vista da reforma litúrgica. Ele apenas confiou ao papado, como um serviço a ser posteriormente realizado, a função de reformar a liturgia ${ }^{76}$.

\section{Do Missal de São Pio V às vésperas do II $^{a}$ Concílio do Vaticano}

Em 14 de julho de 1570, um novo Missal é promulgado pelo papa Pio V e submetido ao uso de toda a Igreja ocidental ${ }^{77}$, com exceção daquelas Igrejas que possuíam ritos com mais de 200 anos de antigüidade. Na preparação deste livro, fruto da urgência e das necessidades

${ }^{72}$ Cf. A. NOCENT, La Messa ..., Op. cit., pp. 40-41.

${ }^{73}$ Cf. G. ALBERIGO, "Dalla uniformità ...", Op. cit., p. 608.

${ }^{74}$ Cf. ibidem, p. 609.

${ }^{75}$ SOCIETAS GOERRESIANA (ed.) Concilii Tridentini Sessio XXV: Super indice librorum, catechismo, breviario et missali: Concilium Tridentinum, Friburgi Brisgoviae, 1901ss, 9,1106

${ }^{76}$ Cf. G. ALBERIGO, “Dalla uniformità ...", Op. cit., p. 610, o qual, contrário à tendência da historiografia tradicional, nega uma plena e coerente correspondência entre as orientações do Concílio e suas deliberações e a atuação do papado no pós-Concílio. Segundo este mesmo autor, nos quatro séculos sucessivos ao Tridentino, a "uniformidade tenazmente perseguida, defendida como um bem essencial, estendida com intransigência aos aspectos mais secundários e minuciosos", teve como "carta magna" as duas bulas de Pio V, a Quod a nobis, que em 6 julho 1568 promulgou o novo Breviário Romano, e a Quo primum, com a qual em 13 de julho de 1570 o mesmo papa publicava o Missal Romano Tridentino, e ainda a criação, por Sisto V, da S. Congregação dos Ritos, com a bula Immensa aeterni Dei, de 22 de janeiro de 1588, instrumento institucional de centralização litúrgica da Igreja (cf. ibidem, pp. 611-612).

77 A imposição do Missal e do Breviário de S. Pio V aconteceu num momento decisivo de "romanização" da Igreja Ocidental, junto a outras formas de atuação do Tridentino, como as visitas apostólicas, o controle dos sínodos e concílios provinciais, a ação dos núncios sobre os bispos (cf. ibidem, p. 613). 
do momento, a comissão elaboradora se limitou a retomar, com poucas correções, um outro Missal ${ }^{78}$. Tratava-se do assim chamado Missale secundum consuetudinem curiae ${ }^{79}$, muito conhecido por ter sido aceito e muito difundido pela Ordem dos Frades menores, que o levaram em todas as suas peregrinações missionárias. Este, na verdade, foi o primeiro Missal impresso como "editio princeps", em Milão, no ano de $1474^{80}$. Mas tal Missal, por sua vez, conforme também já recorda o n. 7 do Proêmio à IGMR (Introdução Geral ao Missal Romano), reproduz com fidelidade um outro, ou seja, o Missal Lateranense do séc.

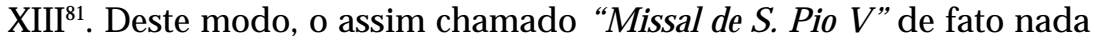
mais é que a edição em pouco corrigida de outros Missais também recentes $^{82}$.

"As correções no Missal tridentino foram, em síntese, de ordem rubrical; tentou-se, sobretudo, de simplificar, reduzindo, por ex., aquelas «apologias» das quais estava embebida a celebração, e que na Idade Média, tinham se multiplicado e desenvolvido em forma exorbitante, fazendo perder de vista a linha harmônica da celebração" ${ }^{83}$.

No Missal de 1570 encontramos, logo de início e em seguida à bula Quo primum tempore de Pio V, uma Rubricae generales Missalis (RGM), uma introdução intitulada Ritus servandus in celebratione Missae e outra chamada De defectibus in celebratione Missarum occurrentibus ${ }^{84}$. A finalidade imediata destas introduções era evitar os

\footnotetext{
${ }^{78}$ Consulte-se sobre isto: A. NOCENT, La Messa ..., Op. cit., pp. 37-52; B. NEUNHAEUSER, "La relation entre le prêtre et les fidèles dans la liturgie de Pie V et celle de Paul VI", in AA.VV., L'Assemblée liturgique et les différents rôles dans l'assemblée (Conférences S. Serge, 23 semaine d'études liturgiques, Paris $1976=$ Bibliotheca 'Ephemerides Liturgicae', 'Subsidia', 9. Roma 1977, pp. 239-252.

79 Cf. M. ANDRIEU (ed.), Missale curiae romanae ou Ordo missalis secundum consuetudinem romanae curiae $d u X^{X I I I^{\circ}}$ siècle, = Miscellanea Ehrle, II. Roma, 1924, pp. 348-376. Cf. I. SCICOLONE, "Livros litúrgicos ...", Op.cit., p. 688, nota 12.

${ }^{80}$ Cf. I. SCICOLONE, "Livros litúrgicos ...", Op.cit., p. 688.

${ }^{81}$ E. AZEVEDO (ed.), Vetus Missale Lateranense, Roma, 1754. Cf. I. SCICOLONE, "L'utilizzazione delle fonti nella riforma liturgica del Vaticano II", Ecclesia Orans 4 (1987) 103.

82 A. NOCENT, La Messa ..., Op. cit., p. 42: “Aquilo que muitos chamam 'o missal de São Pio $V^{\prime}$ é tal na realidade somente porque este papa o promulgou, mas existia já um século antes desta promulgação".

${ }^{83}$ I. SCICOLONE, "L'utilizzazione ...", Op. cit., p. 104.

${ }^{84}$ Até então nenhum Missal, nem os manuscritos da Idade Média, nem as primeiras edições do Missal romano que se sucederam ao de 1474, comportaram uma descrição detalhada das rubricas da missa, como fazia agora o Missal de 1570. Esta constituía então verdadeira novidade. P. Jounel, porém, chama a atenção que tal ausência não nos deve levar a crer ser este primeiro Ritus servandus fruto de uma geração espontânea. Concorreram para a sua elaboração o Ordo Romanus I, o tratado Indutus planeta, intitulado Ordo agendorum et dicendorum a sacerdote in missa privata et feriali iuxta consuetudinem Ecclesix Romanx, que o ministro geral dos Franciscanos, Haymon de Faversham, compôs, em 1243, para assegurar a conformidade entre a prática litúrgica
} 
abusos que se haviam infiltrado na celebração da missa, na medida em que forneciam regras precisas e inflexíveis para todo o seu desenvolvimento. Os Ritus servandus não deixam nenhum espaço à iniciativa individual ou à improvisação; absolutamente tudo está previsto com meticulosidade ${ }^{85}$.

Sobretudo chama a atenção o fato de não se encontrar neste Missal nenhum aceno à assembléia litúrgica, nenhuma rubrica destinada aos fiéis e nem mesmo uma simples palavra sobre a necessidade da participação do povo. Ignora-se completamente a função e o sentido da presença do povo na celebração da Eucaristia, o que de resto já faziam os seus modelos mais imediatos. A assembléia dos fiéis, outrora tão ativa no culto e, por isso, tão citada e valorizada, é aí simplesmente esquecida, não se falando dela em nenhuma parte.

Tais rubricas, que permaneceram invariáveis até os ajustes inseridos em 1911 por Pio $X^{86}$ e até a redação definitiva de todo renovada do Codex Rubricarum de João XXIII em $1960^{87}$, representam em parte o impulso reformador do Concílio de Trento, que aspirava a uma maior unidade na maneira de realizar o culto. Mas antes de mais nada são o resultado de um forte e preciso desejo de fixação, uniformidade e rigidez que se seguiu a este Concílio, chegando a estabelecer uma liturgia unitária, tornada obrigatória a quase toda a Igreja ocidental. Tais rubricas, na verdade, indicam apenas ao sacerdote como deve conduzir a celebração nos seus mínimos particulares, sem levar em conta a assembléia dos fiéis, a não ser em algumas poucas circunstâncias, e assim mesmo, só por acaso. Aqui estamos diante de uma liturgia ao extremo "clericalizada" ${ }^{88}$. Semelhante procedimento tinha por objetivo inculcar na ação litúrgica dignidade, atenção, devoção. Nestas circunstâncias, «celebrar» significava, na prática, ler com escrupulosa exatidão os textos oficiais e realizar com outra tanta escrupulosidade os ritos uniformes, com todas as minúcias fixadas pelas rubricas ${ }^{89}$.

As Rubricae generales Missalis (RGM), utilizando uma linguagem fria, jurídico-formal e sem nenhuma vida, se interessam pela hierarquia e são atentas ao perfeito cumprimento das mínimas rubricas. Mas desconhecem a assembléia do povo bem como seu papel no interior

dos franciscanos com a da Igreja romana, o Directorium divinorum Officiorum, de Luigi Ciconiolani, surgido em 1539, mas sobretudo, o Ordo servandus per sacerdotem in celebratione Missæ sine cantu et sine ministris secundum ritum sanctæ Romanx Ecclesæ, de Jean Burckard, que apareceu em 1498 (Cf. J. P. JOUNEL, Les rites de la messe ..., Op. cit., pp. 6-11).

${ }^{85}$ Cf. ibidem, p. 11.

${ }^{86}$ AAS 3 (1911) 633-651.

${ }^{87}$ AAS 52 (1960) 593-740.

${ }^{88}$ Cf. B. NEUNHAEUSER, "La relation ... “, Op. cit., pp. 241-242.

${ }^{89}$ Cf. L. BRANDOLINI, "Animação", in D. SARTORE / A. M. TRIACCA, Op.cit., p. 48. 
da ação litúrgica. Em apenas dois locais nas Rubricae, mas de forma muito longínqua, o texto considera os assistentes. Trata-se dos nn. $\mathrm{XVI}, 2^{90}$ e XVII, $2^{91}$; mas isso é tudo o que este documento diz dos fiéis presentes à Eucaristia ${ }^{92}$.

Os Ritus servandus in celebratione Missae, elencando os ritos a serem observados, seguem na mesma linha das RGM. Aqui cabe sempre aos ministros, não ao povo, as respostas da Missa. E nas poucas vezes em que os RSCM (Ritus servandus in celebratione Missae) utilizam a palavra populus, o faz de forma puramente estática: o sacerdote benedicit populo dicens: Pater...93. Outras vezes o povo é visto apenas de modo circunstancial, quase comparável a um móvel da igreja, como a credência ou as cadeiras: Celebrans... vertens se ad populum dicit...94. Em apenas um lugar em todo este documento se encontra, por exemplo, o verbo «salutare» em referência ao povo: salutat populum, et dat benedictionem ${ }^{95}$. Já na parte seguinte, De defectibus in celebratione Missarum occurrentibus, não se fala jamais do povo ou dos assistentes.

B. Neunheuser em seu estudo destes documentos aponta todas as vezes em que os RSCM se referem de alguma maneira ao povo ou aos assistentes: II,3; III,9; IV,2; V,1.3; VI,6; VII,3.7.10; VIII,3.5; X,3.6.9; XII,1.896. E no final afirma:

\footnotetext{
90 $\mathrm{O}^{\mathrm{o}} \mathrm{XVI}, 2$ das RGM (Rubricae generales Missalis) assim se exprime: $\mathrm{O}$ sacerdote, pois, deve sobretudo cuidar que o que se deve dizer em voz alta, pronuncie de maneira distinta e apropriada, e não muito depressa, porque se possa perceber o que ele lê, nem demasiadamente devagar, para não entediar os ouvintes, nem também em voz demasiadamente elevada, para não perturbar outros que, por acaso, celebram na mesma Igreja e ao mesmo tempo, nem em voz tão baixa que não possa ser ouvido pelos circunstantes, mas em voz mediana e grave, de maneira que ajude a devoção e seja acomodada aos ouvintes, de forma que se entenda o que se lê. O que se deve recitar em segredo, pronuncie de maneira que ele ouça a si mesmo e não seja ouvido pelos circunstantes (Sacerdos autem maxime curare debet, ut ea quae clara voce dicenda sunt, distincte et apposite proferat, nom admodum festinanter, ut advertere possit quae legit, nec nimis morose, ne audientes trdio afficiat; neque etiam voce nimis elata, ne perturbet alios, qui fortasse in eadem Ecclesia tunc temporis celebrant; neque tam submissa, ut a circumstantibus audiri nom possit, sed mediocri et gravi: quæ et devotionem moveat, et audetibus ita sit accommodata, ut quæ leguntur intelligant. Quæ vero secreto dicenda sunt, ita pronuntiet, ut et ipsemet se audiat, et a circumstantibus nom audiantur).

${ }^{91}$ RGM (Rubricae generales Missalis), n. XVII,2: “Os participantes das missas privadas estejam sempre de joelhos, também no tempo pascal, exceto quando se lê o Evangelho" (Circumstantes autem in Missis privatis semper genua flectunt, etiam Tempore Paschali, praeterquam dum legitur Evangelium).

${ }_{92}$ Cf. B. NEUNHEUSER, "La relation ... ", Op. cit., pp. 242.

${ }^{93}$ RSCM (Ritus servandus in celebratione Missae), XII,1.

${ }_{94}$ Ibidem, XI,2.

${ }^{95}$ Ibidem, V,3.

${ }^{96}$ B. NEUNHAEUSER, "La relation ... “, Op. cit., pp. 242-243.
} 
"Estas rubricas, muito numerosas, precisas e minuciosas, outra coisa não olham que o padre celebrante. É ele e só ele quem deve ser ajudado por elas, a fim de poder celebrar dignamente, corretamente, retamente e de forma uniforme, rubricas estas que serão observadas em toda parte e por todos. Não se fala dos fiéis, a não ser na medida em que sua presença determina a ação do padre. Só por acaso é que se tratará aí dos fiéis. Sua presença não é necessária. Ela, contudo, por vezes é pressuposta, embora permaneça sempre uma presença passiva" ${ }^{97}$.

O Missal de S. Pio V considera como caso «normal» de celebração o tipo «Privado», isto é, a Missa não solene (sem diácono e subdiácono) e sem canto. Esta se chamará também «Missa baixa». Para a celebração de uma «Missa solene» ou "cantada», se juntou no Missal em forma de notas de apêndices ou de suplementos, as indicações necessárias ${ }^{98}$. $\mathrm{Na}$ verdade, chamava-se «Missa privada» aquela celebrada sem a presença do povo, e com um só ministrante ${ }^{99}$.

O Missal assim estruturado, apesar da críticas sofridas logo após a sua promulgação ${ }^{100}$, continuou imutável por quase quatro séculos. Nele

${ }^{97}$ Ibidem p. 243-244.

${ }_{98}$ Cf. ibidem, p. 241.

${ }^{99}$ Para Lutero era, ao invés, «Missa privada» também aquela em que só o sacerdote celebrante comungava sacramentalmente. A isso o Tridentino responderá declarando ser tais Missas "communis", pois nela o sacerdote age como "público ministro da Igreja não só por si mesmo, mas por todos os fiéis que pertencem ao Corpo de Cristo" (DS 1747). A palavra de autoridade do Concílio, porém, fez que a Missa «privada», agora considerada «universal», se tornasse sempre mais uma prática «devota» e «solitária», fortemente recomendada aos sacerdotes, na qual ele era o único a celebrar e a comungar. Isso levou a Missa a se tornar nos últimos anos ainda mais um fato individualista e privado do padre, sem ligação com a comunidade. Assim é que numa mesma igreja não era raro haver contemporaneamente muitas celebrações eucarísticas, com cada padre rezando a «sua» Missa num diverso altar, levados que eram pela mística da «universalidade na solidão». "Eram conseqüências que o Concílio certamente não podia prever, mas isto somente porque a sua teologia abstrata não se inspirou, de forma alguma, na Liturgia, embora se ocupasse daquilo que desde sempre foi e era também então, como o é hoje, o culmen et fons de toda a vida e de toda a Liturgia da Igreja": S. MARSILI, "Teologia da celebração ...", Op. cit., pp. 125-127. Devoção pessoal dos padres e necessidade por parte do povo de obter graças particulares e sufragar os seus mortos são motivos que deram origem às missas privadas. Estas eram ditas assim não só porque cada oferente privatizava para si o seu efeito, mas também porque o sacerdote a celebrava sozinho, quase sempre sem a presença do ofertante. Assim, com o tipo "privado" se dá a passagem da celebração da comunidade, para a celebração para o indivíduo; Idem, La celebrazione liturgica tra storia e teologia: AA.VV., Celebrare il mistero di Cristo [Atti della VI settimana di studio dell'Associazione professori di liturgia, Roma 1977 = Studi di liturgia, 6, Bologna 1978, pp. 95-98). Nas RGM (Rubricae generales Missalis) do Missal tridentino, a expressão «Missa privata» aparece, seja especificando um tipo determinado de Missa (cf. XV,1; XVI,1; XVII,1), seja em distinção à «Missa sollemnis» (cf. XVI,3; XVII,2-3).

${ }^{100}$ Cf. A. NOCENT, La Messa ..., Op. cit., p. 58. 
se introduziram apenas alguns poucos reparos, quase todos concentrados, coisa tanto curiosa como insólita ${ }^{101}$, entre os anos de 1951 a 1962, às portas portanto do Concílio Vaticano $\mathrm{II}^{102}$.

Apesar de tudo, nestes quatro séculos não se pode negar a existência de uma continuada relação entre os fiéis e a Missa. Esta permaneceu sempre um dos pontos essenciais e centrais da vida cristã, e os cristãos a assistiam em grande número, com regularidade e piedosamente $^{103}$. No decurso da celebração, contudo, o povo exercia o simples e único papel de assistente passivo, "só à espera de que o sacerdote terminasse, num altar distante, numa língua desconhecida e com gestos incompreensíveis, a sua missa" ${ }^{104}$.

De outra parte, os séculos XVII e XVIII oferecem novidades a nível de desejo de uma maior participação popular no culto. Foi o caso do Jansenismo, que apresentou uma certa retomada do conceito de assembléia e, entre outras coisas, lutou pelo uso da língua vernácula na liturgia. Identificado, porém, como um movimento atrás do qual se escondia a reforma protestante, foi desprezado e bem cedo condenado. Já o chamado Iluminismo católico, que teve a sua mais alta expressão no Sínodo de Pistoia (1786), lutou pela simplicidade e inteligibilidade dos ritos e dos textos e pelo valor da comunidade dos fiéis. Todavia, eivado de um exagerado racionalismo e de erros doutrinais, não só recebeu uma condenação, como também atrasou, por mais de um século e meio, o necessário processo de reformas ${ }^{105}$.

Mas os descontentamentos gerados pelo rubricismo e formalismo litúrgico e pelo esquecimento quase total do povo fiel e de sua participação nas celebrações encontraram vazão no chamado Movimento Litúrgico ${ }^{106}$. Iniciado nos albores deste século XX, mas deitando suas raízes no século anterior, tal Movimento se constituiu num grande redescobridor da importância da assembléia cultual e fomentador das reformas litúrgicas, enfim empreendidas pelo último Concílio.

\footnotetext{
101 Cf. H. SCHMIDT, La costituzione sulla sacra liturgia. Testo-genesi-commentodocumentazione, Roma, 1966, p. 103.

102 Cf. S. MARSILI, “A Liturgia ...", Op. cit., pp. 103-105.

${ }^{103}$ Cf. B. NEUNHAEUSER, “La relation ... “, Op. cit., pp. 244. 251.

104 S. MARSILI, “Teologia da celebração ...", Op. cit., p. 127.

${ }^{105}$ Cf. G. RAPISARDA, Fasi storiche ..., Op. cit., p. 19. Veja ainda o excelente aprofundamento histórico de E. CATTANEO, Il culto cristiano in occidente. Note storiche = Bibliotheca 'Ephemerides Liturgicae', 'Subsidia', 13, Roma, 1984, pp. 352-451.

${ }^{106}$ Para a história deste Movimento no Brasil, ver J. A. DA SILVA, O Movimento Litúrgico no Brasil: Estudo histórico, Petrópolis: Vozes, 1983.
} 


\section{Assembléia e participação na Constituição Sacrosanctum Concilium}

Na Constituição sobre a Liturgia, fruto estimadíssimo do Concílio Vaticano II, com a qual se encerrou, por assim dizer, o período litúrgico Tridentino, de quatrocentos anos de duração ${ }^{107}$, encontramos os pontos básicos sobre os quais deve girar a futura reforma litúrgica. No primeiro número do proêmio deste documento, a Igreja confessa ser um seu dever interessar-se de modo todo especial pela reforma e incremento da liturgia. Isso porque é na liturgia e, em máximo modo na eucaristia, que «se atualiza a obra da nossa redenção» (SC 2).

Ora, uma tal centralidade da liturgia na vida da Igreja deve-se ao fato de que, exatamente no culto litúrgico, a nossa salvação, alcançada por Cristo, torna-se em realidade atuante. Consciente de ser distribuidora da salvação, a Igreja desde a sua origem pentecostal até hoje, jamais deixou de se reunir em assembléia para celebrar o mistério pascal de seu Senhor (SC 6). A constante presença de Cristo em sua Igreja, em especial na ação litúrgica, é a suprema garantia da realização de semelhante obra.

“Com razão, pois, a Liturgia é tida como o exercício do múnus sacerdotal de Jesus Cristo, no qual, mediante sinais sensíveis, é significada e, de modo peculiar a cada sinal, realizada a santificação do homem; e é exercido o culto público integral pelo Corpo Místico de Cristo, Cabeça e membros" (SC 7).

E muito embora não seja a única atividade da Igreja, a liturgia é culmen et fons da inteira vida eclesial (SC 9-10).

Quanto ao problema que aqui de perto nos interessa, ou seja, o sentido da assembléia eucarística e da participação plena, consciente e frutuosa dos fiéis na mesma, vemos ser com ênfase sublinhado e repetido no documento ${ }^{108}$. A importância tradicional da assembléia litúrgica na vida da Igreja foi, pois, recordada e a justo modo valorizada pela Sacrosanctum Concilium, e seus ensinamentos correspondem à mais autêntica tradição eclesial, enraizando-se profundamente no

\footnotetext{
${ }_{107}$ V. NOÈ, "Storia della Costituzione liturgica. Punti di riferimento", in Costituzione liturgica "Sacrosanctum Concilium», Studi, a cura della CONGREGAZIONE PER IL CULTO DIVINO = Bibliotheca 'Ephemerides Liturgicae', 'Subsidia', 38. Roma, 1986, p. 15: "A data de 4 de dezembro de 1963, na qual se concluía a segunda votação, não podia deixar de indicar uma outra coincidência cronológica. Quatrocentos anos antes, em 4 de dezembro de 1563, o Concílio de Trento chegava ao seu término, após ter confiado a reforma da liturgia ao Papa".

108 Sobre a participação ativa do povo nos atos litúrgicos segundo a Sacrosanctum Concilium, veja um bom comentário em: H. SCHMIDT, La costituzione ..., Op. cit.., pp. 330-338.
} 
$\mathrm{NT}^{109}$. Aí a assembléia dos fiéis retornou ao centro da celebração litúrgica, lugar que tradicionalmente lhe pertenceu, como atesta a mais tenra tradição eclesial. Traduzia-se assim no concreto da celebração a redescoberta teológica da assembléia ${ }^{110}$.

Em pelo menos 25 números da $S C$ a palavra «participar» ou «participação» aparece, promovendo ou exigindo a participação viva e ativa dos fiéis: cf. 11, 12, 14 (duas vezes), 17, 19, 21, 26, 27, 30, 33, 41, 48, 50, $53,55,56,79,90,106,113,114,121,124$ e título antes do $\mathrm{n}^{\circ} 14^{111}$. Isso nos mostra o quanto os padres conciliares estavam conscientes de sua necessidade e a ela eram sensíveis. Como veremos no capítulo sucessivo, muitas destas passagens da SC serão transcritas ou citadas na IGMR. Aqui, porém, comentaremos brevemente algumas destas partes da Constituição que se interessam pela participação na assembléia litúrgica.

O artigo 11 da $S C$, dando aos sagrados pastores aquela função própria do episcopus (evpi, skopoj) no sentido grego do termo, ou seja, de vigia e controlador, exorta-os a vigiarem com cuidado para que os fiéis participem da liturgia ativa e frutuosamente. Esta mesma preocupação com a participação frutuosa e ativa "que a própria natureza da Liturgia exige", retorna no artigo 14 da SC. O n. 19 continua advertindo os pastores de alma a darem instrução litúrgica e a promoverem a participação "cumprindo assim um dos principais deveres do fiel dispensador dos mistérios de Deus". A reforma dos textos e dos ritos, dirá o n. 21, deverá ser conduzida de modo a exprimir com clareza as coisas santas e possibilitar a fácil compreensão e participação plena e ativa do povo cristão na celebração comunitária. De importância singular no que diz respeito à definição do papel da assembléia participante nas ações litúrgicas da Igreja, é o n. 26 da SC, que declara:

"As ações litúrgicas não são ações privadas, mas celebrações da Igreja, que é o «sacramento da unidade», isto é, o povo santo, unido e ordenado sob a direção dos Bispos (S. Cipriano, De Cath. Eccl. Unitate, 7; Cf. Ep. 66, n.8,3). Por isso, estas celebrações pertencem a todo o Corpo da Igreja, e o manifestam e afetam; mas atingem a cada um dos membros de modo diferente, conforme a diversidade de ordens, ofícios e da participação atual".

Como constata S. Marsili ${ }^{122}$, este artigo 26 da SC, na medida em que põe em evidência a hierarquia, entende mesmo superar a relação, até então dominante, de «Liturgia-Igreja hierárquica», como se esta fosse

${ }^{109}$ Cf. J. LÉCUYER, “A Assembléia litúrgica ...”, Op. cit., p. 5.

${ }^{110}$ Cf. G. RAPISARDA, Fasi storiche ..., Op. cit., p. 20.

${ }^{111}$ Cf. H. SCHMIDT, La costituzione ..., Op. cit.., pp. 332.

112 S. MARSILI, "A Liturgia ...", Op. cit., pp. 132-133. 
a única verdadeira ou, ao menos, a primária. Ao mesmo tempo, continua refletindo S. Marsili, chega-se aí a inculcar um princípio «eclesiológico» de primeira ordem, quando se acentua que a «Igrejapovo de Deus na sua totalidade» é o lugar natural onde, apenas, se pode encontrar a Liturgia enquanto celebração atual. Mais ainda, a exemplo da SC 2, a Liturgia aqui é vista como o espaço no qual o «corpo de Cristo» se manifesta e se revela como «Igreja», isto é, na sua verdadeira natureza de «sacramento». Inflamado exatamente por esta nova consciência, o documento conciliar continuará dizendo:

“Todas as vezes que as cerimônias, de acordo com sua própria natureza, admitem uma celebração comunitária, com assistência e participação ativa dos fiéis, seja inculcado que, na medida do possível, ela deve ser preferida à celebração individual ou quase privada. Isso vale, principalmente, para a celebração da Missa e a administração dos sacramentos, naturalmente salvaguardada a natureza pública e social de cada Missa" (SC 27).

No seu n. 30 a SC indica que a participação deve se concretizar nas aclamações do povo, nas respostas, na salmodia, nas antífonas e cânticos, nas ações, gestos e posições do corpo e também no sagrado silêncio. Daí a utilidade da adoção da língua vernácula nas mesmas celebrações (SC 36) e as legítimas variações e adaptações que devem ser introduzidas nas diversas assembléias, regiões e povos (SC 38). Discorrendo sobre o incremento da via litúrgica na diocese e na paróquia, os nn. 41 e 42 da $S C$ fundamenta-a na plena e ativa participação de todo o povo santo de Deus nas mesmas celebrações litúrgicas presididas pelo bispo e presbíteros. Já o n. 48, de imenso valor por enumerar a finalidade das modificações a serem realizadas na liturgia, assim se expressará:

"Por isso a Igreja com diligente solicitude zela para que os fiéis não assistam a este mistério da fé como estranhos ou espectadores mudos. Mas cuida para que bem compenetrados pelas cerimônias e pelas orações participem consciente, piedosa e ativamente da ação sagrada, sejam instruídos pela Palavra de Deus, saciados pela mesa do Corpo do Senhor e dêem graças a Deus. E aprendam a oferecer-se a si próprios oferecendo a hóstia imaculada, não só pelas mãos do sacerdote, mas também juntamente com ele e assim tendo a Cristo como Mediador, dia a dia se aperfeiçoem na união com Deus e entre si, para que, finalmente, Deus seja tudo em todos" (SC 48).

Pensando na liturgia como ação da inteira comunidade reunida, a Constituição litúrgica segue ordenando o retorno da oração dos fiéis, grande elemento de participação de todos na assembléia (SC 53), bem como a possibilidade de se conferir ao povo a comunhão sob as duas espécies em determinadas ocasiões (SC 55). Sobre a participação ativa 
e fácil de todos nos sacramentos trata o $\mathrm{n}^{\circ} 79$ da $S C$; quanto aos cantos litúrgicos a serem executados na Igreja se interessam os nn. 113 e 114 da mesma Constituição. Mas caberá ao capítulo que se interessa pela arte sacra e pelas alfaias pedir que as igrejas a serem construídas sejam funcionais, tanto para as celebrações como para obter a participação ativa dos fiéis (SC 124). O povo é convidado também a tomar parte de forma mais perfeita nas Missas, de modo especial nos domingos e festas de preceito (SC 55 e 56). E sobre a reunião eucarístico-dominical se expressará ainda outra vez em caráter particular a SC 106.

Vemos que nos artigos aqui citados, de maneira clara, repetida e profunda, mas em muitos outros de forma continuada e implícita, a $S C$ se mostra vivamente sensível à questão da participação intensa da assembléia nas celebrações.

Todavia, não basta uma presença qualquer ou uma participação qualquer, mas deve-se criar toda uma sintonia interna com a ação litúrgica, que age como santificação em Cristo e culto a Deus em Cristo. A meta, pois, é a participação plenária externa e interna, a participação ativa, comunitária, hierarquicamente estruturada de todo o povo, convergente na diocese e na paróquia ${ }^{113}$, isto é, no ambiente próprio e natural da assembléia litúrgica.

O conteúdo que a $S C$ apresenta sobre o tema da assembléia e participação é, sem dúvida, surpreendente, e de modo especial, levandose em conta ser este o primeiro documento promulgado pelo Vaticano II.

Após tantos e tantos séculos de imobilismo litúrgico na Igreja, a necessidade de mudanças, em especial, no que se referia à comunidade cultual era, pois, intensa. "O suceder-se dos séculos não pode deixar intata uma liturgia, se esta é vivida: porque cada época, legitimamente, tenta torná-la mais viva e melhor participada" ${ }^{114}$.

\section{Conclusão}

Enfocando a questão da participação da assembléia dos fiéis na celebração eucarística através dos séculos cristãos, pode-se falar em verdadeira $e$-volução deste conceito ou, pelo contrário, realiza-se aí mais uma in-volução?

Na Igreja das origens, a participação viva e intensa comprometia a todos. Os testemunhos que nos são oferecidos pelo Novo Testamento e pela época patrística, base e fundamento para nossas atuais assem-

${ }^{113}$ Cf. C. VAGAGGINI, Il senso teologico ..., Op. cit., pp. 783-792.

114 A. NOCENT, La Messa ..., Op. cit., p. 59. 
bléias eucarísticas, bem ilustram esta realidade. E isso não é difícil de se compreender, pois tínhamos aí um pequeno número de crentes, profundamente animados pela novidade do cristianismo nascente, que encontravam na participação no culto a própria razão de ser e de viver. À medida, porém, em que a Igreja vai crescendo em número de cristãos e se afastando desta matriz inicial, a realidade da participação do povo na vida litúrgica e, em especial, na eucaristia, começa a declinar de forma clara e sensível. Assim, nos inícios da Idade Média, já encontramos problemas sérios quanto à participação dos fiéis nas celebrações.

Um exemplo, a esse propósito, pode bem ilustrar tal realidade. Nos primeiros séculos cristãos, na cidade de Roma, quando a maioria de sua população compreendia e falava bem o grego, a missa era normalmente celebrada nesta língua. Mas, um pouco mais tarde e à medida em que o grego deixa de ser a língua comum desta cidade, dando lugar ao latim, a Igreja acompanha a tendência geral e a missa é logo traduzida em latim ${ }^{115}$, o que demonstra toda uma sensibilidade eclesial em relação à compreensão-participação do povo. Todavia, num momento sucessivo, o latim começa a dar lugar em Roma à língua vulgar e a maioria de sua população não o compreende mais. Aqui, porém, não encontramos aquela mesma sensibilidade em fazer participar $o$ povo, acompanhado o seu modo próprio de se expressar. E, assim, vai permanecer na liturgia do ocidente romano a missa sendo celebrada apenas em língua latina, situação que perdura até pouco mais da metade deste nosso século XX.

Por outro lado, após a paz de Constantino em 313, o fato da missa começar a ser celebrada de preferência nos imensos espaços das Basílicas romanas e não mais, como antes, nas casas particulares dos cristãos (Domus Ecclesiae), vai provocar ainda mais a separação entre povo e liturgia. Nesses novos espaços, a liturgia conhecerá logo a sofisticação cerimonial e a pompa, pela multiplicação dos ritos e gestos, sem que o povo se dê conta do que está sendo celebrado.

Na Idade Média, a dificuldade em se compreender o verdadeiro sentido do culto da assembléia, aliada a uma grande ignorância litúrgica que, pouco a pouco, vai penetrando os meios eclesiásticos, vai alargar as distâncias entre povo e liturgia, ao mesmo tempo em que promoverá o surgimento de anomalias litúrgicas e de uma piedade eucarística, supersticiosa e muito estranha. Essa crise litúrgica no interior da Igreja, unida à forte crítica que os reformadores protestantes lançam, em especial, contra a liturgia católica, receberá uma surpreendente resposta por parte do Concílio de Trento. Reagindo às críticas dos

115 Cf. Th. KLAUSER, La liturgia nella chiesa occidentale. Sintesi storica e riflessioni, Torino: Elle di Ci / Leumann, 1971, pp. 31-38. 
reformadores, o Concílio promoverá o fechamento da Igreja ao mundo circundante e respondendo à crise interna que vitimava, mais que tudo, a maneira de celebrar o seu culto - situação que vinha se alastrando penosamente ao longo de toda a Idade Média - este mesmo Concílio unificará a liturgia.

O Concílio de Trento é, pois, de grande interesse para uma justa compreensão do porque a participação na assembléia eucarística, antes de capital importância para a Igreja, cai num profundo esquecimento, situação que perdura ao longo de quatro séculos. Unificando e enrijecendo a liturgia, as decisões tomadas a partir de Trento afastarão cada vez mais os fiéis da liturgia, comprometendo decisivamente a sua participação. Podemos dizer mesmo que a reforma tridentina como que "oficializa" a não participação do povo na liturgia cristã, tornando-a uma simples especialidade do clero. Os quatro séculos de influência litúrgica deste Concílio serão marcados por um tipo de liturgia eucarística que interessava com exclusividade ao sacerdote celebrante, considerado agora o único ator e agente do culto oficial da Igreja. O povo nada conta e de nada mais participa: apenas assiste silencioso a um ritual belo, mas complicado, executado em uma língua desconhecida da maioria.

Durante os quatrocentos anos que separam o Concílio de Trento do Concílio Vaticano II, não podendo "participar" da liturgia da missa em si, pois tal ato competia exclusivamente ao sacerdote celebrante, o povo por vezes se apropriará de certos elementos litúrgicos periféricos e que, de alguma forma, contornavam a celebração eucarística, sem todavia, tocá-la. Será o caso do canto litúrgico, em especial do canto coral, com suas polifonias, bem como as procissões e encenações litúrgicas. Não obstante tudo, a liturgia permanece intocável, impenetrável e enrijecida - um verdadeiro "monumento" - exatamente como haviam predisposto aqueles que se encarregaram de colocar em prática as decisões litúrgicas do Concílio Tridentino.

Será necessário que o Movimento Litúrgico do início do século XX, grande sopro do Espírito Santo a favor de sua Igreja, comece a conscientizar de novo o povo cristão sobre o significado e valor da liturgia, provocando em seu ardor a realização do importante Concílio Vaticano II, o qual, afinal, dá as indicações para a reforma e incremento da liturgia na Igreja de nossos tempos.

Passamos assim de um período de grande participação do povo na liturgia a um outro, muito longo por sinal, marcado por um paulatino afastamento dos fiéis da vida litúrgica, até se chegar a uma total separação entre povo e celebração. O Vaticano II, porém, preconiza a participação do povo como algo central na vida litúrgica da Igreja. E agora, alguns anos após o Concílio, pensamos nos encontrar de novo num período forte de participação. No Brasil, de um modo todo espe- 
cial, esta participação tem ganhado nos tempos pós-conciliares um grande relevo, sobretudo pela ação de grupos eclesiais que, no coração da Igreja, procuram fazer da participação na eucaristia sua expressão maior.

Mas podemos falar, nestes nossos tempos, de verdadeira participação na eucaristia? E que significa mesmo participar da celebração eucarística? Todos somos de acordo que, para participar ativa e conscientemente, é preciso conhecer o que se participa. Nosso povo fiel, para não falarmos nos sacerdotes, presidentes de celebração, será que compreendem, de fato, a missa? Foi este povo evangelizado o suficiente, catequizado e, de modo geral, iniciado na liturgia? E mais especificamente na compreensão litúrgica da eucaristia? Em nossas paróquias há tempo suficiente para se empreender uma significativa catequese litúrgica? E estamos, de fato, conscientes de que tal catequese é mesmo essencial? A participação na liturgia se reduz apenas ao exterior, aos gestos visíveis, ou exige repercussão e comprometimento interior?

A liturgia é a realidade central da vida do cristão. No hoje de cada celebração litúrgica, concretiza-se de modo efetivo e eficaz, a realidade de nossa salvação. A reforma litúrgica talvez já tenha conseguido fazer muito na Igreja, mudando o exterior de tantos gestos, símbolos e ritos. E isso até que não foi difícil realizar nestes trinta e tantos anos que nos separam do Concílio. Mas, se a mesma reforma não teve condições ainda de nos conscientizar sobre a realidade central do que vem a ser liturgia, será que podemos nos ufanar de que agora participamos e participamos bem da celebração? Podemos já proclamar a vitória de nossas liturgias reformadas?

"Efetivamente podemos afirmar que o 'participar da celebração' se realiza por meio da ação externo-ritual (gestualidade, ritualidade, linguagem, língua, adaptação litúrgica), mas não se esgota somente no âmbito dos sinais litúrgicos usados de modo adequado e apropriado. 'Participar da celebração' significa transcender e ultrapassar o âmbito semântico-ritualista para penetrar no 'cerne' da ação litúrgica. Em outros termos: a participação externa (a que é feita de atitudes externas: responder, cantar, levantar-se, ajoelhar-se ou ficar de joelhos etc.) é apenas o primeiro estágio da 'participação na celebração', que é a 'ensimesmação' subjetiva e objetiva ao 'mysteriumsacramentum'" 116 .

É verdade que hoje em dia, melhor do que em qualquer outra época, temos ótimas condições de promover em nossas assembléias

${ }^{116}$ A. M. TRIACCA, “Participação”, in D. SARTORE / A. M. TRIACCA, Op. cit., p. 887. 
litúrgico-eucarísticas uma verdadeira e intensa participação, pois a reforma da liturgia promovida pelo último Concílio do Vaticano já nos ofereceu todas as possibilidades para tal. A participação, porém, não surge do nada e não nasce gratuitamente, mas exige sempre desejo sincero de realizá-la, entusiasmo na sua execução e grande disposição para torná-la efetiva. Só depois disso poderemos afirmar sem nenhuma sombra de dúvida que nossa ação litúrgica de fato tem e-voluído no sentido mais pleno deste termo.

Pe. José Raimundo de Melo SJ, obteve o título de Mestre em Liturgia no Pontifício Instituto Litúrgico do Pontifício Ateneo Santo Anselmo de Roma, em 1997, e de Doutor em Liturgia, no mesmo Instituto, em 1993, com a tese $A$ assembléia eucarística nos documentos do Magistério no Pós-Concílio. É Assessor de Liturgia da Dimensão Litúrgica da CNBB nacional, coordenador do Curso de pós-graduação, com especialização em Liturgia, no Instituto de Teologia da Universidade Católica do Salvador (BA) e membro da ASLI (Associação dos Liturgistas do Brasil).

Endereço: Av. Leovigildo Filgueiras, 683 - Garcia 40100-000 - Salvador - BA. e-mail: josermelo@zipmail.com.br 